\title{
Passifloraceae sensu stricto no Parque Estadual da Serra do Brigadeiro, Minas Gerais, Brasil ${ }^{1}$
}

\author{
Passifloraceae sensu stricto in the Serra do Brigadeiro State Park, Minas Gerais, Brazil
}

\author{
Andreza Magro Moraes ${ }^{2,5}$, Michaele Alvim Milward-de-Azevedo ${ }^{3} \&$ Ana Paula Gelli de Faria ${ }^{4}$
}

\begin{abstract}
Resumo
O presente estudo visou inventariar a diversidade taxonômica da família Passifloraceae sensu stricto no Parque Estadual da Serra do Brigadeiro (PESB), Minas Gerais e investigar os aspectos ecológicos relacionados à distribuição, estado de conservação e ocorrência das espécies em diferentes classes de altitude dentro da área de estudo. Foram identificadas 11 espécies pertencentes ao gênero Passiflora, a saber: P. alata, P. amethystina, P. capsularis, $P$. edulis, $P$. filamentosa, $P$. mediterranea, $P$. miersii, $P$. porophylla, $P$. rhamnifolia, $P$. speciosa e $P$. tetraden, das quais quatro são novos registros de ocorrência para o PESB ( $P$. alata, $P$. capsularis, $P$. filamentosa e $P$. rhamnifolia). A maioria das espécies está enquadrada em categoria de ameaça de extinção regional, com exceção de $P$. filamentosa e $P$. miersii, classificadas como "Deficiente de Dados", e $P$. speciosa e $P$. mediterranea consideradas "Menos Preocupante". Apenas $P$. alata e P. rhamnifolia atingiram as maiores elevações na área, em campos de altitude (1.700-1.800 m).
\end{abstract}

Palavras-chave: Domínio Atlântico, Floresta Ombrófila, Passiflora, Serra da Mantiqueira.

\begin{abstract}
The present study goal was to survey the taxonomic diversity of Passifloraceae sensu stricto in the Serra do Brigadeiro State Park (PESB), Minas Gerais and to investigate the ecological aspects related to the distribution, state of conservation and occurrence of the species in different altitude classes within the study area. Eleven species of the genus Passiflora were identified: P. alata, P. amethystina, P. capsularis, P. edulis, P. filamentosa, P. mediterranea, P. miersii, P. porophylla, P. rhamnifolia, P. speciosa and P. tetraden, of which four are new records for the PESB ( $P$. alata, $P$. capsularis, $P$. filamentosa and $P$. rhamnifolia). Most of the species are considered endangered at a regional level, with exception of $P$. filamentosa and $P$. miersii, classified as "Data Deficient", and P. speciosa and P. mediterranea, considered as "Least Concern". Only $P$. alata and $P$. rhamnifolia reached the highest elevations in the area, in campos de altitude $(1.700-1.800 \mathrm{~m})$. Key words: Atlantic Domain, Ombrophilous Forest, Passiflora, Serra da Mantiqueira.
\end{abstract}

\section{Introdução}

No Brasil, a família Passifloraceae Juss. sensu stricto ocorre por todo o território, domínios fitogeográficos e vegetações, e compreende cerca de 150 espécies referentes aos gêneros: Ancistrothyrsus Harms, Dilkea Mast., Mitostemma Mast. e Passiflora
L. que é o gênero mais representativo, com maior riqueza de espécies nos domínios Amazônico (74 spp.) e Atlântico (73 spp.) (BFG 2015).

O estado de Minas Gerais apresenta uma grande diversidade de Passifloraceae sensu stricto com registro de dois gêneros (Mitostemma e

\footnotetext{
${ }^{1}$ Parte da dissertação de Mestrado da primeira autora.

${ }^{2}$ Universidade Federal de Juiz de Fora, Inst. Ciências Biológicas, Prog. Pós-graduação em Ecologia, Campus Universitário, R. José Lourenço Kelmer s/n, Bairro São Pedro, 36036-900, Juiz de Fora, MG, Brasil.

${ }^{3}$ Universidade Federal Rural do Rio de Janeiro, Inst. Três Rios, Depto. Ciências do Meio Ambiente, Av. Prefeito Alberto da Silva Lavinas 1847, Centro, 25802-100, Três Rios, RJ, Brasil.

${ }^{4}$ Universidade Federal de Juiz de Fora, Inst. Ciências Biológicas, Depto. Botânica, Campus Universitário, R. José Lourenço Kelmer s/n, Bairro São Pedro, 36036-900, Juiz de Fora, MG, Brasil.

${ }^{5}$ Autor para correspondência: andrezamagro@hotmail.com
} 
Passiflora) e 50 espécies nativas, dentre elas quatro endêmicas e algumas espécies raras (BFG 2015). Importantes trabalhos sobre a flora de Passifloraceae sensu stricto foram publicados para o estado (Cervi 1994, 1996, 2006; Vitta 2006; Farinazzo \& Salimena 2007; Milward-de-Azevedo 2007; Fontes et al. 2013; Mezzonato-Pires et al. 2013; Bernacci et al. 2014). No entanto, para aumentar as informações sobre distribuição geográfica, ecologia e taxonomia da família é importante a manutenção e o aumento de pesquisas e expedições científicas em ambientes pouco explorados ou ainda inexplorados.

O Parque Estadual da Serra do Brigadeiro (PESB) abriga um importante remanescente de Floresta Atlântica do estado de Minas Gerais, e apresenta um conjunto de serras pertencentes à Serra da Mantiqueira, sendo considerada uma área de prioridade extremamente alta para conservação (MMA 2007). Representa uma das últimas áreas de florestas de encosta Atlântica primitivas ainda existentes no estado de Minas Gerais (Leoni 1992). O levantamento da flora do PESB realizado por Leoni \& Tinte (2004) indicou a presença de cinco espécies de Passifloraceae sensu stricto, sendo: Passiflora amethystina J.C. Mikan., P. edulis Sims., P. miersii Mart., P. speciosa Gardner. e P. tetraden Vell. Porém, até o momento, não existe nenhum estudo específico sobre taxonomia, morfologia, ecologia ou conservação a cerca de espécies de Passifloraceae sensu stricto no PESB.

Com isso, o objetivo do trabalho foi ampliar o conhecimento sobre a diversidade taxonômica, estado de conservação e distribuição da flora de Passifloraceae sensu stricto no PESB e de modo geral no estado de Minas Gerais e no domínio Atlântico.

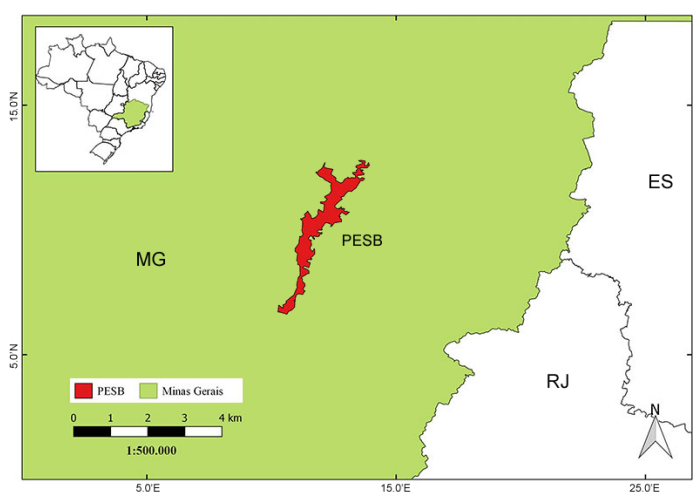

Figura 1 - Localização do Parque Estadual da Serra do Brigadeiro, Minas Gerais, Brasil.

Figure 1 - Location of the da Serra do Brigadeiro State Park, Minas Gerais, Brazil.

\section{Material e Métodos}

O PESB está localizado entre as latitudes $42^{\circ} 40^{\prime}$ e $40^{\circ} 20^{\prime} \mathrm{S}$ e as longitudes $20^{\circ} 33^{\prime}$ e $21^{\circ} 00^{\prime} \mathrm{W}$, no estado de Minas Gerais, Região Sudeste do Brasil (Fig.1). Possui uma área total de 14.984 ha e altitude, variando entre $900 \mathrm{~m}$ até $1.985 \mathrm{~m}$ (Benites 1997). O clima da região é do tipo mesotérmico médio $(\mathrm{CWb})$ de acordo com o sistema de classificação de Köppen (1948). A temperatura média anual é de $18{ }^{\circ} \mathrm{C}$, com a média mínima de inferior a $10{ }^{\circ} \mathrm{C}$, e média máxima é de $23{ }^{\circ} \mathrm{C}$, atingindo temperaturas inferiores a $0{ }^{\circ} \mathrm{C}$ nos meses frios (Engevix 1995). A precipitação média anual varia em torno de 1.500 mm (Benites et al. 2001). A área está inserida no domínio Atlântico, com formações fitogeográficas de Florestas Ombrófilas, Campos de Altitude, Campos Higrófilos, além de áreas de pastagens e cafezais em regeneração florestal em áreas adquiridas há menos tempo, e florestas em estágio sucessional secundário devido ao intenso corte de árvores para obtenção de madeira realizada por longo período antes da consolidação da UC (Minas Gerais 2007).

Foram realizadas expedições ao campo no período de julho de 2014 a junho de 2015 para coleta de material fértil. As coletas foram herborizadas segundo Vaz et al. (1992) e depositados no Herbário Leopoldo Krieger (CESJ), acrônimo segundo Index Herbariorum (Thiers, continuously updated). As descrições foram elaboradas com base no material coletado em campo e material dos herbários CESJ, ESA, HUEMG, IAC, RB, UPCB e VIC acrônimos segundo Index Herbariorum (Thiers, continuously updated). Para algumas espécies foi analisado material complementar, de coletas provenientes preferencialmente do estado de Minas Gerais em áreas próximas ou similares ao PESB. Todas as amostras podem ser conferidas na lista de exsicatas ao final do trabalho.

Para caracterização das estruturas vegetativas e reprodutivas foram utilizadas as classificações de Rizzini (1977) e Beentje (2012), para descrição das sementes o trabalho de Pérez-Cortéz \& Escala (2002), e como complemento Harris \& Harris (2001) e Stearn (2004). As mensurações das lâminas foliares bilobadas e/ou trilobadas foram realizadas de acordo com Milward-de-Azevedo \& Baumgratz (2004), com algumas modificações (Fig. 2a-c): as medidas do comprimento das lâminas foram obtidas das nervuras medianas (nm) de folhas bilobadas e trilobadas (Fig. 2a,b), já as larguras das lâminas foram consideradas como as distâncias dos ápices dos lobos laterais (Fig. 2a,b-larg.). Para cada lobo (médio-lm, lateral-1l), foram medidos o comprimento 
e largura (Fig. 2b-x,y). Para as folhas inteiras (Fig. 2c) o comprimento (comp.) foi obtido na medida da nervura central, da base até o ápice, e a largura na mediana da folha (larg.). As espécies foram ilustradas com base no material coletado no PESB, destacando as estruturas importantes na identificação. $\mathrm{E}$ foi elaborada uma chave de identificação para a família no PESB.

As espécies em estágio reprodutivo ou vegetativo identificadas no território do PESB tiveram as coordenadas geográficas e elevação dos locais de ocorrência registrados, listados e organizados em planilhas e plotados em mapas. Estes dados foram utilizados para a análise do estado de conservação regional no PESB das espécies, utilizando o programa ArcView GIS 3.2 e a extensão CATS (Conservation Assessment Tools) (Moat 2007). Foi adotado o uso de Grid de $4 \mathrm{~km}^{2}$ para o cálculo da Área de Ocupação (AOO), conforme é recomendado pela IUCN (ICMBIO 2013). Está análise foi baseada nos critérios estabelecidos pela International Union for Conservation of Nature (IUCN) (IUCN 2001) (ICMBIO 2013). As informações utilizadas para a categorização foram provenientes das populações ocorrentes dentro da Unidade de Conservação ou em zona de amortecimento. A decisão final da categoria foi ajustada alterando a categorização para um nível maior ou menor de ameaça ou mantendo a categorização preliminar de acordo com o que é recomendado pela IUCN (ICMBIO 2013). E para espécies com apenas um ou dois pontos de ocorrência, $P$. filamentosa e $P$. miersii, não foram calculados os parâmetros, por não formar ao menos um triângulo, para possibilitar o cálculo.

Os dados de elevação de cada espécie registrados em campo foram listados e organizados em 11 classes de altitude de $100 \mathrm{~m}$, em uma matriz de presença e ausência analisada no software PAST
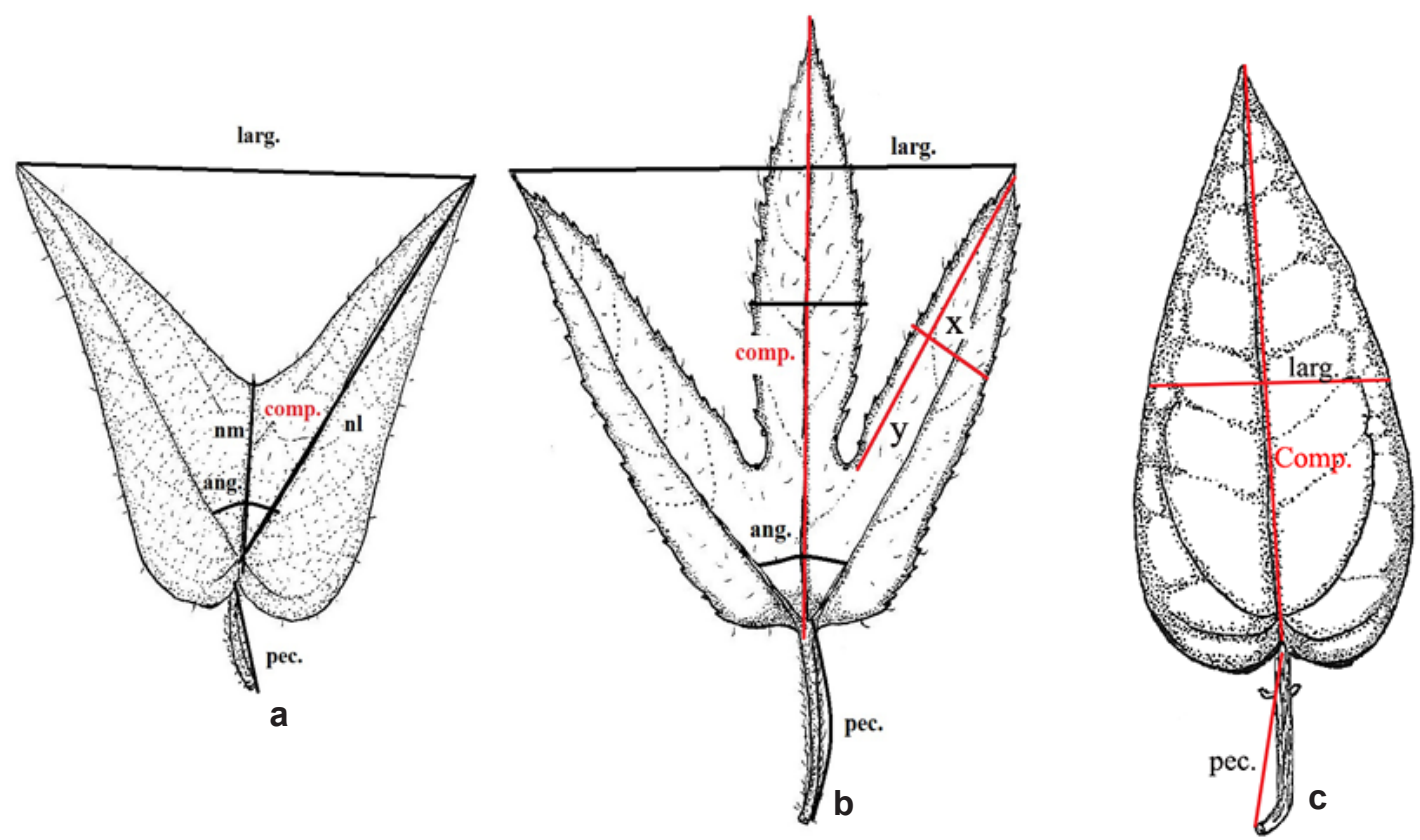

Figura 2 - a-c. Contorno das folhas demonstrando o método de medidas - a. Passiflora capsularis - folha bilobada (comp. = comprimento da lâmina foliar; larg. = largura da lâmina foliar; $\mathrm{nm}=$ comprimento da nervura mediana; ang. = ângulo formado entre as nervuras laterais e principais; $\mathrm{nl}=$ comprimento da nervura lateral; pec. = comprimento do pecíolo); b. Passiflora speciosa - folha trilobada (comp. = comprimento da lâmina foliar; larg. = largura da lâmina foliar; ang. = ângulo formado entre as nervuras laterais e principais; $\mathrm{x}=$ largura do lobo lateral e central; $\mathrm{y}=$ comprimento do lobo lateral e central; pec. $=$ comprimento do pecíolo); c. Passiflora mediterranea - folha inteira $($ comp. $=$ comprimento da lâmina foliar; larg. = largura da lâmina foliar; pec. = comprimento do pecíolo). Desenhado por Andreza M. Moraes. Figure 2 - a-c. Contour of the leaf demonstrating the method of measures - a. Passiflora capsularis - bilobed leaf (comp. $=$ length of the leaf blade; larg. = width of the leaf blade; $\mathrm{nm}=$ length of the median vein; ang. = angle formed between the side and main veins; $\mathrm{nl}=$ length of the side vein; pec. = lenght of the petiole); b. Passiflora speciosa - leaf 3-lobed (comp. = lenght of the leaf blade; width. $=$ width of the leaf blade; ang. = angle formed between the side and main veins; $\mathrm{x}=$ width of the lobe side and central; $\mathrm{y}=$ lenght of the side and central lobe; pec. = lenght of the petiole); c. Passiflora mediterranea - entire leaf (comp. = lenght of leaf blade; larg. = width of the leaf blade; pec. $=$ lenght of the petiole). Drawn by Andreza M. Moraes. 
(Hammer \& Harper 2001) e foi gerado um gráfico de distribuição por altitude.

\section{Resultados e Discussão}

Foram registradas 11 espécies de Passifloraceae sensu stricto, representantes do gênero Passiflora, a saber: Passiflora alata Curtis, $P$. amethystina, $P$. capsularis L., $P$. edulis, $P$. filamentosa Cav., P. mediterranea Vell., P. mierii, $P$. porophylla Vell., P. rhamnifolia Mast., P. speciosa e $P$. tetraden. Dentre estes quatro novos registros são apresentados para a área de estudo: $P$. alata, $P$. capsularis, $P$. filamentosa e $P$. rhamnifolia. Todas as espécies encontradas no estudo são nativas do Brasil, sendo P. alata, P. amethystina, P. capsularis, P. filamentosa, P. mediterranea, P. porophylla, $P$. speciosa e $P$. tetraden endêmicas do Domínio Atlântico (Cervi et al. 2009; BFG 2015).

No estudo realizado por Leoni \& Tinte (2004) foram citadas apenas cinco espécies de Passifloraceae no PESB. Já de acordo com o plano de manejo realizado em 2006, foram indicadas para o PESB seis espécies, a saber: Passiflora amethystina, P. edulis, P. miersii, P. setacea DC., P. speciosa e P.tetraden (Minas Gerais 2007). No entanto, durante as coletas em campo e visitas aos herbários não foram encontrados registros de $P$. setacea, inclusive no Herbário VIC, onde estaria depositada de acordo com o plano de manejo. Dentre as espécies ocorrentes no PESB, P. speciosa é a que mais se assemelha a $P$. setacea devidos as suas folhas trilobadas, e possivelmente poderia ser identificada erroneamente considerando apenas os caracteres vegetativos.

Passiflora setacea é uma espécie nativa dos domínios da Caatinga, Cerrado e Atlântico e ocorre principalmente em áreas de transição cerrado-caatinga, restingas, cerrado latu sensu e no semi-árido do norte de Minas Gerais (Oliveira \& Ruggiero 2005; BFG 2015). É típica de ambiente quente e seco, diferente do clima serrano, úmido e chuvoso encontrado na Serra do Brigadeiro. Como não foi possível confirmar sua ocorrência no PESB, acredita-se que o registro seja um erro de identificação.

Conservação e classes de altitude das espécies de Passifloraceae sensu stricto ocorrentes no PESB

As espécies diferiram nos padrões de distribuição e ocorrência no PESB. Passiflora mediterranea foi à espécie com mais ampla distribuição, sendo observada em diversos tipos de ambientes, mas principalmente em áreas abertas com grande exposição ao sol e na borda de trilhas.

A Área de Ocupação (AOO) de Passiflora mediterranea $(138,51)$ e $P$. amethystina $(107,34)$ foram as maiores, seguidas por $P$. speciosa $(82,4)$ (Tab. 1). Já a Extensão de Ocorrência (EOO) foi maior para $P$. alata $(154,2)$ e $P$. mediterranea $(123,99)$, seguidas por $P$. porophylla $(92,4)$ e $P$. speciosa $(91,46)$. As espécies de menor ocorrência, e consequentemente de $\mathrm{AOO}$ e EOO, foram $P$. edulis $(7,71 ; 10,26)$ e $P$. rhamnifolia $(9,68 ; 7,14)$, encontradas em apenas um ou dois pontos do PESB (Fig. 3; Tab. 1).

As espécies Passiflora amethystina, $P$. capsularis, $P$. mediterranea, $P$. porophylla, P. tetraden e P. speciosa (Fig. 3b,c,f,h, $\mathrm{j}, \mathrm{k}$ ) apresentaram ampla distribuição, ocorrendo tanto na porção norte quanto ao sul do PESB, com indivíduos observados em praticamente todos os pontos explorados, demonstrando um hábito mais generalista ao se adaptarem a diversos tipos de ambientes. Exceto por P. capsularis, que ocorreu somente em dois pontos, a beira de trilhas (Serra do Tabuleiro e Trilha do Carvão), que se caracterizam pela forte influência antrópica devido a sua utilização para travessia pelos moradores das comunidades rurais.

Já as espécies Passiflora alata, P. edulis, $P$. filamentosa, $P$. miersii e $P$. rhamnifolia apresentaram distribuição restrita a área norte (Fig. 3a,d,e,g,i), sendo P. miersii e P. rhamnifolia restritas a Fazenda Brigadeiro e Pico do Boné, em Floresta Ombrófila e na borda das trilhas (Fig. 3e,i). Passiflora filamentosa foi registrada somente na Fazenda Brigadeiro. A região norte do PESB apresenta um clima mais úmido com florestas mais densas se comparadas à porção sul que possui clima mais quente e seco e fragmentos florestais mais afunilados, consequentemente com maior efeito de borda. Isso pode estar influenciando na distribuição de determinadas espécies para cada região.

As espécies Passiflora filamentosa, $P$. rhamnifolia e P. speciosa, são trepadeiras lenhosas, apresentaram caule com diâmetro grande (ca. $5 \mathrm{~cm}$ ) e às vezes subterrâneos, demonstraramse mais expressivas no interior da floresta e no sub-bosque. De acordo com Dewalt et al. (2000) espécies de lianas são mais abundantes e diversas em florestas mais jovens do que em florestas adultas. A proporção de trepadeiras que utilizam gavinhas para aderir ao substrato diminui, enquanto aumentam as lianas com caule volúvel em florestas 
Tabela 1 - Categorias do estado de conservação de acordo com a International Union of Conservation Nature $\left(\mathrm{N}^{\mathrm{o}}\right.$ loc. = número de localidades; EOO = extensão de ocorrência; EOO_RAT = classificação pela extensão de ocorrência; $\mathrm{AOO}$ = área de ocorrência; AOO_RAT= classificação pela área de ocorrência).

Table 1 - Categories of the conservation status of according with International Union of Conservation Nature $\left(\mathrm{N}^{\circ}\right.$ loc. $=$ number of locations; EOO = extent of occurrence; EOO_RAT = classification by extent of occurrence; AOO = area of occurrence; AOO_RAT = classification by area of occurrence.

\begin{tabular}{lcclcl}
\hline Espécies & No $^{\mathbf{l}}$ loc. & EOO & EOO_RAT & AOO & AOO_RAT \\
\hline Passiflora alata & 12 & 154,20 & Vulnerável & 94,54 & Vulnerável \\
Passiflora amethystina & 17 & 71,27 & Em perigo & 107,34 & Vulnerável \\
Passiflora capsularis & 12 & 27,70 & Criticamente em perigo & 18,78 & Em perigo \\
Passiflora edulis & 3 & 10,26 & Criticamente em perigo & 7,71 & Criticamente em perigo \\
Passiflora filamentosa & 1 & 0,00 & Deficiente em dados & 0,00 & Deficiente em dados \\
Passiflora mediterranea & 75 & 123,99 & Menos preocupante & 138,51 & Menos preocupante \\
Passiflora miersii & 1 & 0,00 & Deficiente em dados & 0,00 & Deficiente em dados \\
Passiflora porophylla & 36 & 92,40 & Em perigo & 58,77 & Vulnerável \\
Passiflora rhamnifolia & 13 & 7,14 & Criticamente em perigo & 9,68 & Criticamente em perigo \\
Passiflora tetraden & 22 & 78,19 & Em perigo & 70,46 & Vulnerável \\
Passiflora speciosa & 31 & 91,46 & Menos preocupante & 82,40 & Menos preocupante \\
\hline
\end{tabular}

mais antigas. Dessa forma, acredita-se que no interior das florestas em áreas mais preservadas prevaleçam espécies de lianas, como estas Passiflora lenhosas especializadas para "escalar" árvores de maior diâmetro. Por outro lado, áreas perturbadas, clareiras, bordas de trilhas ou florestas, são geralmente habitadas por trepadeiras herbáceas ou sub-lenhosas (Gentry 2009) como ocorreu com P. capsularis, $P$. mediterranea, $P$. porophylla e $P$. tetraden.

$\mathrm{Na}$ avaliação do status de conservação de acordo com o cálculo da AOO e EOO, a maioria das espécies se enquadra em alguma categoria de ameaça de extinção regional, conforme observado na Tabela 1. Somente Passiflora filamentosa e P. miersii foram classificadas em "Deficiente de Dados" de acordo com os resultados obtidos na análise e $P$. mediterranea e $P$. speciosa levando em consideração o grande número de seus indivíduos encontrados no campo tiveram o resultado ajustado e ambas foram consideradas como "Menos Preocupante".

Por outro lado, destas espécies chegou a ser analisada pela Lista Nacional Oficial de Espécies da Flora Ameaçada de Extinção e o Livro Vermelho da Flora do Brasil (Martinelli \& Moraes 2013; MMA 2014) nenhuma das espécies se encontra ameaçada. Passiflora porophylla se encontra categorizada como Em Perigo e P. edulis como Quase Ameaçada no estado do Rio Grande do Sul (Consema 2003).
Na análise altimétrica, as espécies distribuíramse entre 1.000 e $1.800 \mathrm{~m}$ (Fig. 4). Passiflora alata foi a que alcançou maior altitude, encontrada em campo de altitude arbustivo e afloramento rochoso, e distribui-se por todas as classes de altitude. A seguinte a atingir altitude mais elevada foi $P$. rhamnifolia também presente em campo de altitude. Já $P$. amethystina, $P$. mediterranea, $P$. porophylla e $P$. speciosa, apresentaram uma distribuição mais ampla, concentrada em altitudes medianas, sendo que $P$. mediterranea ocorreu desde a primeira classe de altitude. Passiflora capsularis e $P$. tetraden se limitaram às menores altitudes e faixa do gradiente, demonstrando maior especificidade. As demais espécies $P$. edulis, $P$. filamentosa e $P$. miersii, também apresentaram ocorrência restrita a uma pequena faixa do gradiente, porém tiveram apenas um ou dois registros de ocorrência.

O estudo demonstrou ocorrência das espécies em elevações acima dos 1.000 m. Porém, em geral, as lianas apresentam aumento de sua diversidade em menores latitudes e em elevações mais baixas. Em grandes altitudes a temperatura é mais baixa e poucas espécies de lianas conseguem tolerar essa condição ambiental mais extrema (Schnitzer \& Bongers 2002). Como observado neste trabalho, algumas espécies conseguiram atingir elevações maiores que outras, possivelmente por possuírem ou terem desenvolvido maior resistência ou adaptação a baixas temperaturas. 

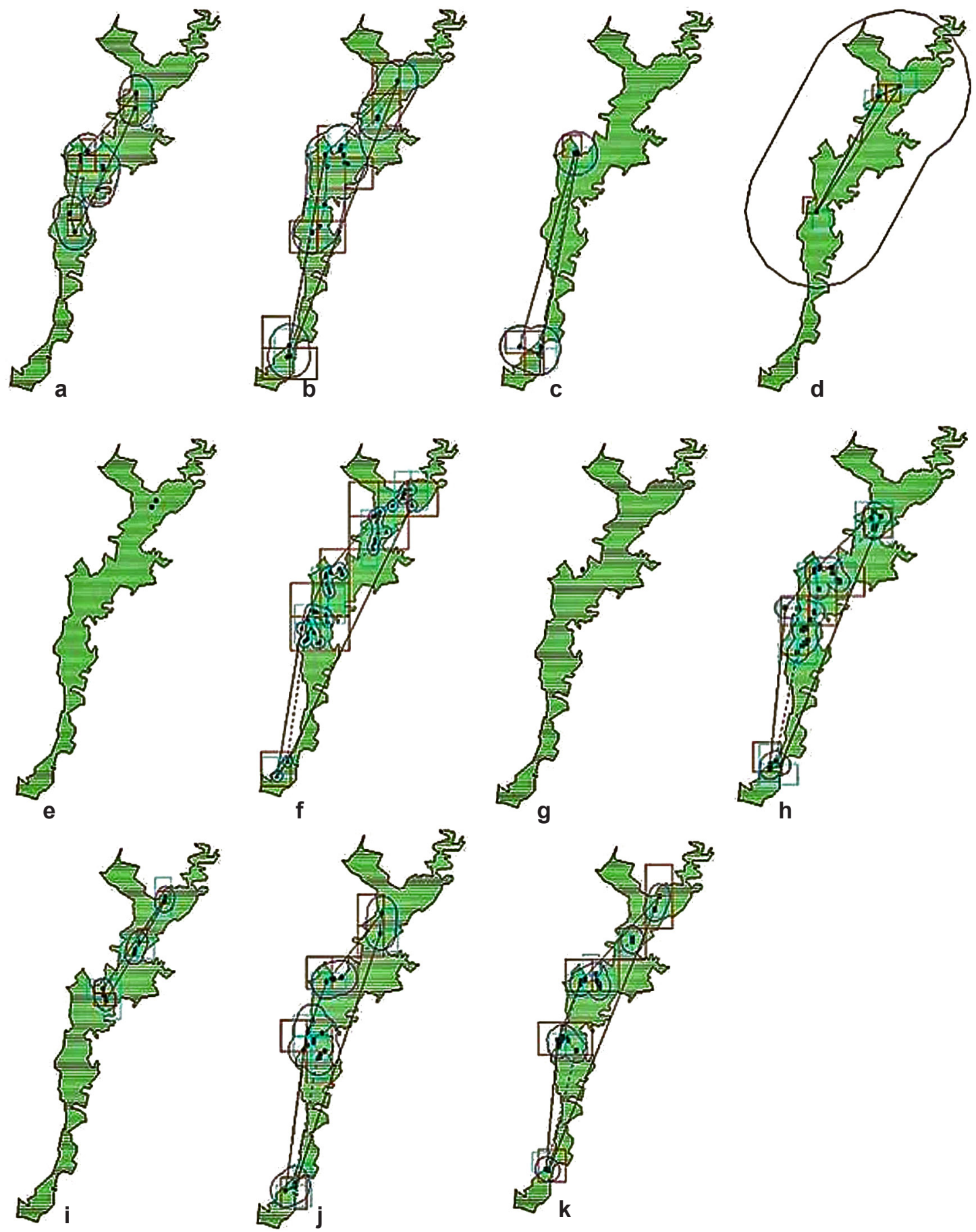

Figura 3 - a-k. Distribuição geográfica das espécies no Parque Estadual da Serra do Brigadeiro - a. Passiflora alata; b. Passiflora amethystina; c. Passiflora capsularis; d. Passiflora edulis; e. Passiflora filamentosa; f. Passiflora mediterranea; g. Passiflora miersii; h. Passiflora porophylla; i. Passiflora rhamnifolia; j. Passiflora tetraden; k. Passiflora speciosa. (AOO = área de ocorrência; EOO = extensão de ocorrência).

Figure 3 - a-k. Geographic distribution of the species in the Serra do Brigadeiro State Park - a. Passiflora alata; b. Passiflora amethystina; c. Passiflora capsularis; d. Passiflora edulis; e. Passiflora filamentosa; f. Passiflora mediterranea; g. Passiflora miersii; h. Passiflora porophylla; i. Passiflora rhamnifolia; j. Passiflora tetraden; k. Passiflora speciosa. $(\mathrm{AOO}=$ area of occurrence; EOO= extent of occurrence). 
As espécies Passiflora amethystina, $P$. capsularis, P. porophylla e P. speciosa demonstraram expressiva plasticidade fenotípica na forma das folhas e/ou disposição das glândulas. Esta plasticidade é comumente observada em Passiflora como já observado no subgênero Decaloba, e nas espécies $P$. edulis e P. alata (Milward-de-Azevedo \& Baumgratz 2004; Cutri et al. 2013).

\section{Tratamento taxonômico}

Passiflora L. Sp. Pl. 2: 955, 1753.

Trepadeiras lenhosas a herbáceas, escandentes. Caule cilíndrico a quadrangular, levemente estriado a sulcado. Estípulas setáceas, lineares ou subreniformes, com arista, múcron ou ausente, ápice agudo a aristado, base arredondada, margem inteira a crenada. Folhas com pecíolos com um par de glândulas sésseis cupuliformes a oblatas, e/ ou pedunculadas urceoladas a ovais, ou ausentes; lâminas foliares membranáceas a coriáceas, inteiras a 5-lobadas, com lobos divergentes ascendentes, lineares a arredondados, com ápice agudo a arredondado, apiculado ou não, base arredondada a cuneada, subpeltada ou não, margem inteira, serreada a glandular-serreada, oceolos presentes ou ausentes, glândulas presentes ou ausentes no sino dos lobos, variegada na face adaxial ou não. Inflorescência mônades pedunculadas. Brácteas alternas a verticiladas, oval a linear-subuladas, margem inteiras a serreadas, cedo caducas, persistentes ou ausentes. Flores com sépalas ovadas a oblongo-ovadas, ápice obtuso a arredondado, com arista foliácea ou não; pétalas oblongas a oblonga-ovadas, ápice obtuso; corona unisseriada a múltiplas séries, filamentos livres ou unidos na base; opérculo cupuliforme a plicado, margem recurvada a filamentosa; límen anelar a cupuliforme ou ausente; androginóforo; anel nectarífero presente ou ausente; ovário globoso a elíptico. Frutos bagas a capsulas loculicidas, globosos a elíptico-sulcados. Sementes obovadas a obcordadas achatadas com ou sem margem alada, ápice com um corno ou ausente, base arredondada a truncada, testa retículo-alveolada a transversalmente sulcada.

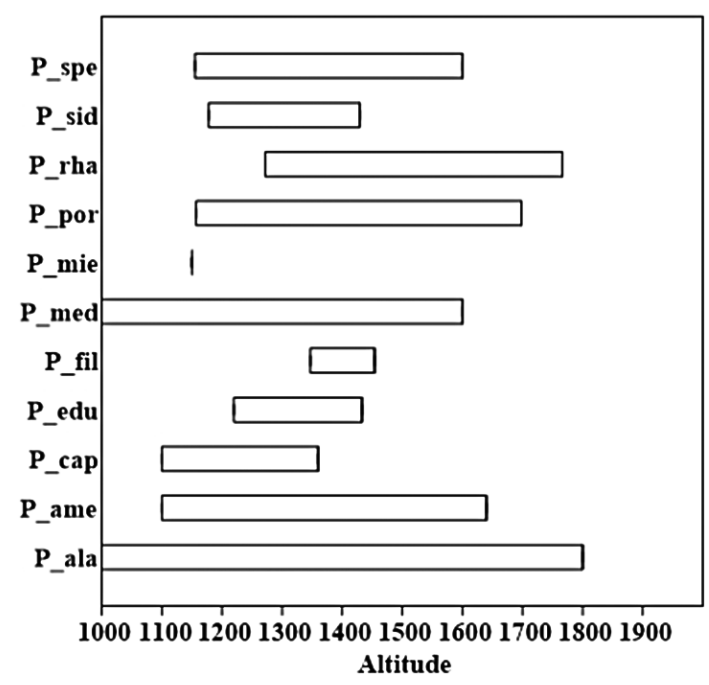

Figura 4 - Gradiente de altitude das espécies de Passifloraceae no Parque Estadual da Serra do Brigadeiro, MG. $\left(\mathrm{P} \_\right.$ala $=$Passiflora alata $; \mathrm{P} \_$ame $=$Passiflora amethystina $; \mathrm{P}_{-}$cap $=$Passiflora capsularis $; \mathrm{P}_{-}$edu $=$ Passiflora edulis; $; \mathrm{P}_{-}$fil $=$Passiflora filamentosa $; \mathrm{P}_{-}$med $=$ Passiflora mediterranea $; \mathrm{P} \_$mie $=$Passiflora miersii; $\mathrm{P} \_$por $=$Passiflora porophylla $; \mathrm{P}_{-}$rha $=$Passiflora rhamnifolia $; \mathrm{P}_{-}$sid $=$Passiflora tetraden $; \mathrm{P}_{-}$spe $=$ Passiflora speciosa).

Figure 4-Gradient of altitude of the species of Passifloraceae in

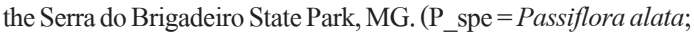
$\mathrm{P}$ _ame $=$ Passiflora amethystina $; \mathrm{P}_{-}$cap $=$Passiflora capsularis ; $\mathrm{P} \_$edu $=$Passiflora edulis $; \mathrm{P}_{-}$fil = Passiflora filamentos $a ; \mathrm{P}_{\text {_med }}$ $=$ Passiflora mediterranea $; \bar{P}_{\_}$mie $=$Passiflora miersii $; \mathrm{P}_{\mathbf{p}}$ por $=$ Passiflora porophylla; $\mathrm{P}_{-}$rha $=$Passiflora rhamnifolia $; \mathrm{P}_{-} \mathrm{sid}=$ Passiflora tetraden $;$ P_spe $=$ Passiflora speciosa $)$.

\section{Chave de identificação das Passifloraceae sensu stricto ocorrentes no Parque Estadual da Serra do Brigadeiro, Minas Gerais, Brasil}

1. Pecíolos com glândulas, lâminas foliares inteiras, 3-lobadas ou 5-lobadas, flores com corona bisseriada a múltiplas séries , opérculos cupuliformes a membranosos, sementes com testa reticulada, finamentereticulada, alveolada, retículo-alveolada, retículo-foveada ........................................................... 2

1'. Pecíolos desprovido de glândulas, lâminas foliares bilobadas, flores com corona unisseriada, opérculos plicados, sementes com testa sulcada transversalmente

2. Brácteas lineares subuladas, flores com filamentos externos da corona subdolabriformes, ovários sulcados, frutos sulcados 9. Passiflora rhamnifolia

2'. Brácteas ovadas a ovado-lanceoladas, flores com filamentos externos da corona subulados a filiformes, ovários desprovido de sulcos, frutos desprovidos de sulcos ...................................... 3

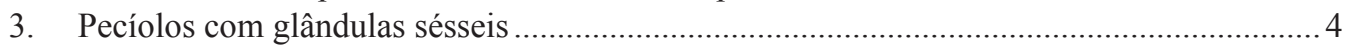


3'. Pecíolos com glândulas pedunculadas .

4. Lâminas foliares 3-lobodas, sementes obovadas sem margem alada

4. Passiflora edulis

4'. Lâminas foliares 5-lobadas, sementes obcordadas com margem alada

5. Passiflora filamentosa

5. Caules quadrangulares com ângulos alados 1. Passiflora alata

5'. Caules cilíndricos ou angulares, sem ângulos alados. 6

6. Trepadeiras com indumento tomentoso, estípulas setáceo-falcadas, flores com corona bisseriada. 10. Passiflora speciosa

6'. Trepadeiras glabras ou com indumento pubescente a pubérulo, estípulas lineares a subreniformes, flores com corona tri a pentasseriada................................... 7

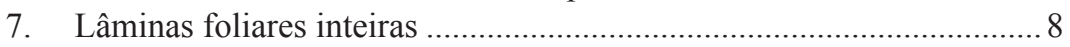

7'. Lâminas foliares inteiras com o ápice ligeiramente trilobado a lâminas foliares trilobadas

8. Lâminas foliares membranáceas a subcoriácea, estípulas semi-ovadas com margem crenada. 7. Passiflora miersii

8'. Lâminas foliares coriáceas a cartáceas, estípulas subreniformes com a margem inteira. 6. Passiflora mediterranea

9. Lâminas foliares inteiras com ápice ligeiramente trilobado com lobo médio mais proeminente e laterais reduzidos, brácteas alternas, ovadas a orbiculares, conjunto de três brácteas com uma menor abaixo de duas maiores, flores com ovário ovoide glabro, frutos ovoide glabro 11. Passiflora tetraden

9'. Lâminas foliares trilobadas com todos os 3-lobos desenvolvidos, brácteas verticiladas ovado-lanceoladas de tamanhos iguais, flores com ovário ovoide a obovado pubescente, frutos elípticos pubescentes. 2. Passiflora amethystina

10. Lâminas foliares com oceolos, flores com filamentos da corona dolabrifomes, frutos bagas.

8. Passiflora porophylla

10'. Lâminas foliares desprovidos de oceolos, flores com filamentos da corona filiformes, frutos capsulas

3. Passiflora capsularis

1. Passiflora alata Curtis Bot. Mag. 2: t. 66, 1788.

Figs. 5; 9a-e

Trepadeira glabra. Caule quadrangular, robusto, alado. Estípulas $6-11 \times 1-3 \mathrm{~mm}$, lanceolado-ovadas a ensiformes. Folhas com pecíolo 1,2-2,2 cm compr., 1-2 pares de glândulas cupuliformes, dispostas 6-21 $\mathrm{mm}$ compr. da base, sésseis a pedunculadas; lâminas membranáceas a subcoriáceas, inteiras, ovadas a lanceolado-oblongas, 5,7-14,5 $\times$ 4,5-7,5 cm, ápice acuminado a agudo, base subcuneada, margem inteira, oceolos ausentes. Mônades, pedunculadas; pedúnculos 2,4-4,7 cm compr. Brácteas 1,6-2,2 × 0,8-1,2 cm compr., verticiladas, lanceolado-ovadas a subuladas, persistentes. Flores carmim, vermelho escuro a púrpura; pedicelos $2-4 \mathrm{~mm}$ compr.; sépalas
2,2-4,4 × 1-2,4 cm, ápice obtuso, dorso com arista 6-7 mm compr., subcoriáceas, face abaxial verde; pétalas 3,2-5,7 × 1-2 cm, ápice obtuso; corona tetrasseriada, base bandeada de roxo escuro e alvo, ápice roxo a alvo, filamentos roxos, vináceos a azul-escuro, os externos 3,2-5,5 cm compr., livres, subulado, às vezes bifurcados, ápice filiforme agudo, os internos reduzidos 0,5-1 mm compr., triangulares ou turbinados, ápice agudo, roxos; opérculo 4-5 mm compr., horizontalmente estendido para dentro, margem encurvada e denticulada; límen anular; coluna do androginóforo 1,5-1,8 cm compr., presença de um anel nectarífero na região mediana; filetes 6-9 mm compr., anteras 10-13 × 3-5 mm; ovário 9-11 × 3-5 mm, oblongo, glabro; estiletes 5-9 $\mathrm{mm}$ compr. Frutos bagas 6,5-7,5 × 3,5-4,7 cm, 
verdes a amarelados com máculas verde-claro, obovoides a ovoides. Sementes ca. $7 \times 5 \mathrm{~mm}$, obovadas, ápice com um corno, base cordada, testa reticulo-foveada.

Material examinado: Araponga, PESB, Trilha do Carvão-Boné, 17.I.2015, bot., A.M. Moraes et al. 342 (CESJ). Fervedouro, PESB, Pedra do Pato, 22.XII.2015, bot. e fl., A.M. Moraes 305 (CESJ); Portaria Pedra do Pato, 18.IX.2014, fr., A.M. Moraes et al. 289 (CESJ). Pedra Bonita, PESB, 15.I.2015, bot., A.M. Moraes et al. 364 (CESJ).

Passiflora alata ocorre na América do Sul (Argentina, Brasil, Paraguai e Peru). No Brasil distribui-se nos estados do Acre, Amazonas, Alagoas, Bahia, Paraíba, Pernambuco, Sergipe, e nos estados das regiões Centro-Oeste, Sudeste e Sul, ocorrendo nos domínios Amazônico, Cerrado e na Floresta Atlântica, em vegetação de área antrópicas, Campos Rupestres, Floresta Ombrófila, Restinga, principalmente em capoeiras, capoeirões e próximas a formações arbóreas (Cervi 1997; Imig 2013; BFG 2015). Na Serra do Brigadeiro foi encontrada em ambientes abertos, na borda das matas e estradas, áreas antrópicas, interior de matas e afloramentos rochosos, especialmente na Pedra Pato onde cobre uma grande extensão do afloramento rochoso. Coletada com flor em julho e dezembro, e com fruto em setembro. As flores foram visitadas por mamangavas (Ordem: Hymenoptera, Família: Apidae, Subfamília: Apinae).

Pode ser identificada pelo caule quadrangular com ângulos alados, e também
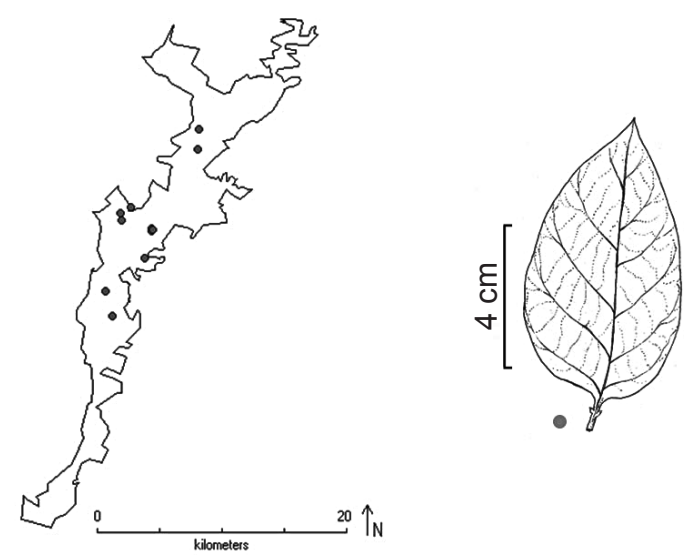

Figura 5 - Distribuição de Passiflora alata no Parque Estadual da Serra do Brigadeiro, MG. Desenhado por Luiz Menini Neto.

Figure 5 - Distribution of Passiflora alata in the Serra do Brigadeiro State Park, Minas Gerais. Drawn by Luiz Menini Neto. se caracteriza por ser totalmente glabra, com folhas inteiras membranáceas a subcoriáceas, com 1 a 2 pares de glândulas no pecíolo, pelas flores vermelho-escuras à púrpuras, robustas, com sépalas subcoriáceas com face abaxial verde e pelos frutos bagas verdes a amarelados com máculas verde-claras.

2. Passiflora amethystina J.C. Mikan Del. Fl. Et. Faun. Bras. 4: 39-40, t.20, 1820 (-1825).

Figs. 6; 9f-j

Trepadeiras escandente, herbácea, glabra, pubescente apenas no ovário, base do estilete e frutos, pecíolo esparso, tricomas filiformes a subulados, unicelulares, adpressos ou não. Caule cilíndrico, levemente estriado. Estípulas 18-48 $\times$ 4-18 mm, linear a oblonga-lanceolada, ápice agudo a mucronado, base arredondada, margem inteira ou glandular-serreada, múcron 1-3 mm compr. Folhas com pecíolos 1,6-6,4 cm compr., 3-8 glândulas dispersas, clavadas, obovadas a tubulares, dispostas 2-15 mm compr. da base, pedunculadas; lâminas foliares membranáceas a subcoriáceas, 3-lobadas, lobos oblongolanceolados a oblongo-ovados, 4-11,2 × 5,1-13,6 $\mathrm{cm}, 2,1-6,1 \times 2-3,5 \mathrm{~cm}(\mathrm{~lm}), 2,5-5,4 \times 1,1-3$ cm (11), ângulo divergente $40^{\circ}-75^{\circ}$, ápice agudo, obtuso, apiculado ou não, base arredondada, cordada a hastada, subpeltada, margem inteira a levemente glandular-serreada, oceolos ausentes, 5 glândulas cupuliformes na margem dos lobos. Mônades, pedunculadas; pedúnculos 0,5-5,8 cm compr. Brácteas 1,7-1,8 ×0,6-0,7 cm, verticilada, lanceolada-ovada, cedo caducas. Flores roxas claro, lilases ou brancas; pedicelos 3-5 mm compr.; sépalas 2,5-2,6 × 0,5-0,7 cm, ápice obtuso, com arista foliácea $1-1,2 \mathrm{~cm}$ compr.; pétalas 2,4-2,5 × 0,4-0,6 cm, ápice obtuso; corona pentasseriada, roxos a brancos, base roxo-escura, ápice alvo, filamentos roxos, lilases a brancos, os externos 0,9-3,2 cm compr., livres, lingulados, parte superior filiforme, ápice agudo, os internos 2-5 mm compr., roxos, filiformes, ápice capitado a espatulado; opérculo ca. $7 \mathrm{~mm}$ compr., com margem inferior recurvada, revoluta, inteira, com processos dentiformes na parte interior, extremidade superior filamentosa a subulada com ápice agudo a crenado; límen cupuliforme, margem ondulada; coluna do androginóforo 1,1-1,2 cm compr.; filetes 6-8 mm compr. com máculas vináceas, anteras 8-11 × 2-4 mm; ovário 5-9 × 1,5-4 mm, ovoide a obovado, pubescente, verdes; estiletes 7-14 mm compr. com máculas 
vináceas. Frutos bagas ca. 2,3 × 2,1 cm, verdes a amarelados, elíptico, pubescente. Sementes 5-6 $\times 2-3 \mathrm{~mm}$, obovadas, ápice com um corno, base aguda, testa alveolada.

Material examinado: Araponga, PESB, Chapada do Rochedo, 10.VI.1993, bot. e fl., M.F. Vieira 799 (VIC); 9.IV.1995, fl., L.S. Leoni 2890 (UPCB); sede, 21.VII.2014, fl., A.M. Moraes 286 (CESJ); Pico do Boné, 1.XI.2014, bot., A.M. Moraes et al. 301 (CESJ); Fazenda Brigadeiro, trilha Lage D'Ouro, 14.I.2015, bot., A.M. Moraes et al. 321 (CESJ). Fervedouro, PESB; Pedra do Pato, 16.X.2014, bot., A.M. Moraes 298 (CESJ). Miradouro, PESB, Serra do Tabuleiro, 26.II.2015, bot., A.M. Moraes \& L.P. Gurgel 351 (CESJ).

Passiflora amethystina ocorre na Argentina, Bolívia, Brasil e Paraguai (Deginani 2001). No Brasil distribui-se nos estados das regiões CentroOeste, Sudeste e Sul (BFG 2015), ocorrendo no Cerrado, Floresta Atlântica e Pantanal, em Floresta Ombrófila, Floresta Estacional Semidecidual, Floresta Ombrófila Mista e em áreas com influência antrópica (Cervi et al. 2009; BFG 2015). É típica de solos arenosos em lugares úmidos, áreas de encostas elevadas, bordas de florestas e beira de estradas. No PESB foi coletada em áreas alagadas, abertas, brejo arbustivo, beira de riachos e interior de florestas em ambiente sombreado.

Foi coletada em botão floral em janeiro e com flor em setembro. As lâminas foliares variaram na sua forma, distância dos ângulos divergentes, largura dos lobos, forma do ápice e textura. As formas mais comuns representam-se por lâminas 3-lobadas com ápice obtuso, lobos de largura
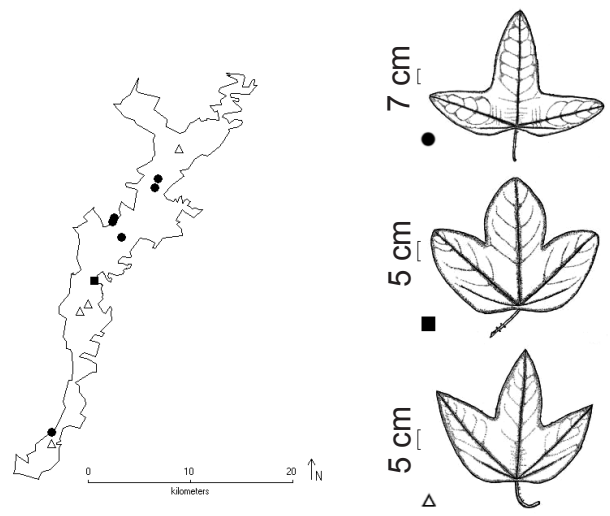

Figura 6 - Distribuição de Passiflora amethystina no Parque Estadual da Serra do Brigadeiro, MG. Desenhado por Andreza M. Moraes.

Figure 6 - Distribution of Passiflora amethystina in the Serra do Brigadeiro State Park, MG. Drawn by Andreza M. Moraes. menor $(1,5-1,8 \mathrm{~cm})$ e ângulo maior $\left(60^{\circ}-75^{\circ}\right)$ (•) e lâminas com lobos de ápice agudo, largura mediana $(1,8-2 \mathrm{~cm})$ e ângulo menor $\left(40^{\circ}-42^{\circ}\right)$ (A) (Fig. 6). A menos frequente, encontrada em um brejo, apresenta lâmina 3-lobada com lobos de ápice obtuso, largura dos lobos maior (2,1-2,6 $\mathrm{cm})$ e ângulo menor $\left(40^{\circ}-50^{\circ}\right)(\boldsymbol{\square})$ além de flores brancas, diferentemente do que é habitualmente observado (A.M. Moraes 286 CESJ).

Pode ser identificada na área de estudo pelo hábito herbáceo, escandente, estípulas lineares a oblonga-lanceoladas com ápice mucronado, lâminas foliares 3-lobadas, membranáceas a subcoriáceas, pecíolo com 3 a 8 glândulas pedunculadas. Flores brancas a lilases com corona de filamentos brancos a roxos e frutos elípticos pubescentes.

\section{Passiflora capsularis L., Sp. P1. 2: 957. 1753.}

Figs. 7; 9k-n

Trepadeira herbácea, com indumento nos ramos, caule, gavinhas, pecíolos, face abaxial das lâminas foliares densamente pubescente, pedúnculo, pedicelo, brácteas, hipanto, sépalas esparso pubescente, face adaxial das lâminas e ovário densamente pubérulo, tricomas filiformes e subulados, unicelulares, adpressos ou não. Caule angular, estriado. Estípulas 2-5 $\times$ ca. $0,5 \mathrm{~mm}$ compr., linear-subuladas. Folhas com pecíolo 1-2,8 cm compr., glândulas ausentes; lâminas membranáceas, inteiras, bilobadas lobos divergentes ascendentes, linear a lanceolados, $3,1-12,5 \times 2,1-10,7 \mathrm{~cm}, 1,8-4,5 \times 1-2,5 \mathrm{~cm}$ (11), ângulo divergente $20^{\circ}-37^{\circ}$, ápice agudo a obtuso, apiculado, base cordada, subpeltada, margem inteira, oceolos ausentes, face adaxial variegada ou não. Mônades, pedunculadas; pedúnculos 1,3-2,7 cm compr. Brácteas ausentes. Flores alvas a esverdeadas; pedicelos ca. $5 \mathrm{~mm}$ compr.; sépalas ca. 1,4 $\times 0,4 \mathrm{~cm}$, ápice obtuso; pétalas ca. $6 \times 15$ $\mathrm{mm}$, ápice obtuso; corona unisseriada, base e ápice alvo, filamento alvos 9-11 mm compr., unidos na base, filiformes, ápice agudo a arredondado; opérculo 3-3,5 mm compr., membranoso, plicado, ápice ereto; límen anular; coluna do androginóforo 8-9 mm compr.; filetes 3,5-4 mm compr., anteras 2-3 × 1-2 mm; ovário 3-3,5 × ca. $2 \mathrm{~mm}$, elíptico, denso pubérulo; estiletes $3-3,5 \mathrm{~mm}$ compr. Frutos capsulas loculicidas $1,6-3,6 \times 0,3-1$ $\mathrm{cm}$, verde, oblongo-lanceolados a lanceolados, pubérulos. Sementes ca. $3 \times 1,5-2 \mathrm{~mm}$, obovadas, ápice com um corno, base aguda, testa sulcada transversalmente. 
Material examinado: Araponga, PESB, Chapada do Rochedo, 10.VI.1993, fr., M.F. Vieira 796 (VIC); 15.I.2015, bot., A.M. Moraes \& M.A. Milward-deAzevedo 365 (CESJ); trilha do Carvão-Boné, 17.I.2015, bot. e fl., A.M. Moraes et al. 335 (CESJ). Ervália, PESB, Serra do Tabuleiro, 26.II.2015, bot. e fl., A.M. Moraes \& L.P. Gurgel 350 (CES).

Passiflora capsularis distribui-se no México (América do Norte), Colômbia, Equador, Brasil, Paraguai e Uruguai (América do Sul) (Milward-deAzevedo \& Baumgratz 2004). No Brasil, distribuise nos estados do Pará, Bahia, Piauí, Goiás, Mato Grosso do Sul, e nas regiões Sudeste e Sul. Ocorre nos domínios Atlântico, Cerrado, Caatinga e Amazônico, em Floresta Estacional Semidecidual, Floresta Ombrófila, Floresta Ombrófila Mista, Restinga, Savana Amazônica, cerrado stricto sensu, cerrado lato sensu e áreas antrópicas (BFG 2015). Também ocorre em bordas de florestas, capoeiras, capoeirões, vegetação secundárias (Cervi 1997; Milward-de-Azevedo et al. 2012). No PESB somente foi encontrada em áreas com forte influência antrópica e em "trilhas de servidão", que são ou foram utilizadas pelas comunidades vizinhas ao parque para deslocamento, além das áreas de amortecimento ao redor do PESB.

Floresce e frutifica em janeiro e fevereiro no PESB. Suas folhas apresentam plasticidade fenotípica com lâminas 2-lobadas com lobos médios (ca. 3,3 cm) ( $\mathbf{\square})$, alongados (ca. 4,2 cm) ( $\boldsymbol{\Delta})$ e curtos (ca. $2 \mathrm{~cm})(\bullet)$, todos com ápice agudo (Fig. 7). Todas as formas ocorrem simultaneamente na área norte do PESB, e ao sul somente as de lobos curtos $(\bullet)$. Devido ao reduzido número de coletas

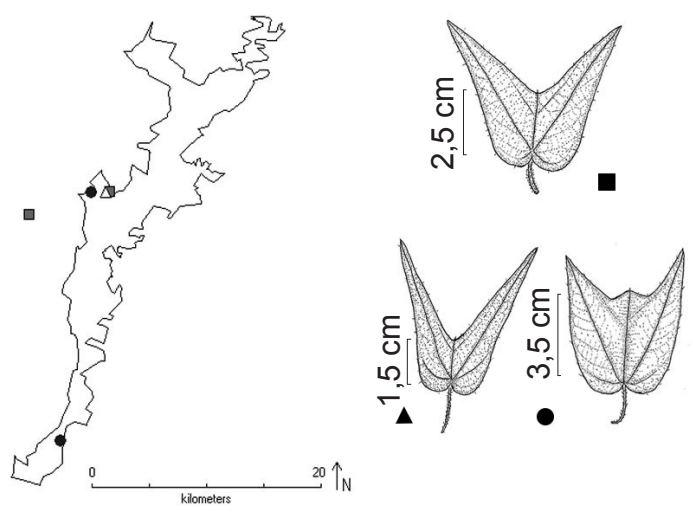

Figura 7 - Distribuição de Passiflora capsularis no Parque Estadual da Serra do Brigadeiro, MG. Desenhado por Andreza M. Moraes.

Figure 7 - Distribution of Passiflora capsularis in the Serra do Brigadeiro State Park, MG. Drawn by Andreza M. Moraes. não é possível aferir o que influencia na distribuição de cada forma (Fig.7). Na trilha Carvão houve uma sobreposição de formas, indicando que nesta região as formas não variam de acordo com o ambiente.

Passiflora capsularis se assemelha a $P$. porophylla Vell., ambas pertencentes ao subgênero Decaloba, pelas lâminas foliares 2-lobadas, estípulas subuladas e pecíolo com glândulas ausentes. A variação da morfologia foliar das duas espécies também faz com que sejam confundidas na forma vegetativa. Porém, são distinguidas pelas flores roxas, frutos bagas e presença de oceolos nas folhas de $P$. porophylla.

Pode ser identificada pela presença de indumento pubérulo a pubescente por toda a planta, pecíolo desprovido de glândulas, lâminas foliares bilobadas com oceolos ausentes, brácteas ausentes, flores brancas com corona de filamentos brancos, unisseriados, filiformes, opérculo plicado e fruto tipo cápsula-loculicida.

4. Passiflora edulis Sims, Rev. Bot. 45: pl. 1989. 1818.

Figs. $8 ; 90-\mathrm{s}$

Trepadeiras lenhosas, glabras a denso pubescentes no ovário e fruto, pubérulos no filete, estilete e androginóforo; tricomas filiformes, unicelulares, adpressos ou não. Caule cilíndrico, estriado, levemente sulcado. Estípulas 5-7 mm compr., linear-subuladas. Folhas com pecíolo 1,8-2 cm compr., um par de glândulas curtamente estipitadas, dispostas no ápice do pecíolo 16-20 mm compr. da base, sésseis; lâminas foliares subcoriáceas a membranáceas, 3-lobadas, lobos divergentes lanceolados a oblongo-lanceolados, 7,3-10 × 6,5-9,6 cm, 4,7-7,3 × 2,1-3,6 cm (lm), $3,4-5,8 \times 1,5-2,8 \mathrm{~cm}$ (11), ângulo divergente $35^{\circ}-55^{\circ}$, ápice agudo a acuminado, base cordada, subpeltada, margem serreada, oceolos ausentes, face adaxial lustrosa. Mônades, pedunculadas; pedúnculos ca. 2,8 cm compr. Brácteas $1-1,6 \times$ 0,7-0,9 cm, verticiladas, ovadas, margem serreada, persistentes. Flores brancas a lilases; pedicelos 2-2,5 mm compr.; sépalas 1,5-1,7 ×0,5-0,6 cm, ápice obtuso, arista no dorso 4-5 mm compr., face abaxial pubescente a esparso; pétalas 1,5-1,7 × 0,5$0,6 \mathrm{~cm}$, ápice obtuso; corona tetra a pentasseriada, base roxo, ápice alvo, filamentos roxos e brancos, os externos 1,5-1,7 cm compr., livres, lingulados, ápice filiforme, os internos 0,5-1,5 mm compr. ou reduzidos, lineares e subulados, ápice agudo e arredondado, roxos; opérculo 5-6 mm compr., ápice inteiro, encurvado; límen cupuliforme; coluna do androginóforo ca. 1,8 cm compr.; presença de 1 
anel nectarífero; filetes ca. $6 \mathrm{~mm}$ compr., anteras ca. $7 \times 2 \mathrm{~mm}$; ovário ca. $5 \times 3 \mathrm{~mm}$, ovoide, denso pubescente; estiletes $9-10 \mathrm{~mm}$ compr. Frutos bagas ca. 2,8 $\times 2,7 \mathrm{~cm}$, verdes, globosos, com mácula verde-claro, esparso a pubérulo. Sementes ca. 6 $\times 3 \mathrm{~mm}$, obovadas, ápice com um corno pequeno, base aguda arredondada, testa finamente reticulada Material examinado: Araponga, PESB, 5.X.1995, fl., L.S. Leoni 3109 (UPCB); Fazenda Brigadeiro, trilha Matipó, 23.XII.2014, fr., A.M. Moraes et al. 309 (CESJ). Material complementar: BRASIL. MINAS GERAIS: Lima Duarte, 15.X.2011, fl., F.R.G. Salimena \& P.H. Nobre 2841 (CESJ).

Passiflora edulis é encontrada na América do Sul (Argentina, Brasil, Colômbia, Equador, Paraguai, Peru e Venezuela), América Central (Bermudas, Costa Rica, Cuba, Guatemala, Jamaica, Martinica, Porto Rico e Trindade) e na América do Norte (Estados Unidos/Havaí). Na Austrália e Havaí são muito cultivadas (Cervi 1997). No Brasil distribui-se por todo país, com exceção do Acre, Amapá, Roraima e Rondônia. Está presente nos domínios Atlântico, Cerrado, Caatinga, Amazônico e Pantanal (BFG 2015). Ocorre em borda de floresta, capoeiras e capoeirões, em solos úmidos e bem drenados (Cervi 1997), assim como em áreas antrópicas, floresta ciliar, Floresta Estacional Semidecidual, Floresta Ombrófila e Ombrófila Mista, vegetação de restinga, cerrado lato sensu e formações campestres (BFG 2015; Cervi et al. 2009). No PESB foi coletada em área aberta e em vegetação secundária ainda em regeneração e floresta ombrófila.
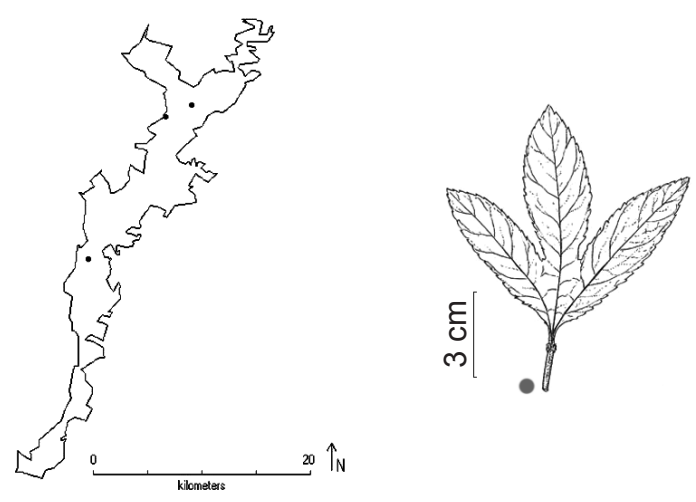

Figura 8 - Distribuição de Passiflora edulis no Parque Estadual da Serra do Brigadeiro, MG. Desenhado por Luiz Menini Neto.

Figure 8 - Distribution of Passiflora edulis in the Serra do Brigadeiro State Park, MG. Drawn by Luiz Menini Neto.
No PESB floresce em outubro e frutifica em dezembro. $\mathrm{Na}$ área pode ser confundida com Passiflora filamentosa Cav. principalmente pela semelhança de seus frutos verdes com máculas verde-claras, além das folhas membranáceas a subcoriáceas de margem serreadas. No entanto podem ser distinguidas pelo número de lobos nas folhas, sendo as de $P$. edulis trilobadas e as de $P$. filamentosa pentalobada. Além disso, as flores se distinguem pelo opérculo filamentoso em $P$. filamentosa e encurvado em $P$. edulis e pelas sementes obcordadas e margem alada em $P$. filamentosa.

Pode ser identificada pelo aspecto glabro, folhas trilobadas lustrosas, um par de glândulas estipitadas no ápice do pecíolo, estípulas linearsubuladas e brácteas verticiladas, ovadas com margem serreada. As flores são brancas com filamentos da corona roxos e brancos e presença de um anel nectarífero, frutos globosos com máculas verde-claras e sementes obovadas com ápice com um corno pequeno, base aguda arredondada e testa finamente reticulada.

5. Passiflora filamentosa Cav., Monadelphiae Classis Dissertationes Dezem 10: 462, t. 294. 1790.

Figs. 10; 13a-e

Trepadeiras escandentes, lenhosas, glabras ou esparsamente pubescentes nos ramos, gavinhas, pecíolos, pedúnculo, pedicelo, brácteas, hipanto e face abaxial das sépalas, lâminas foliares glabras ou esparsamente vilosas; tricomas filiformes, unicelulares, adpressos ou não. Caule cilíndrico, estriado. Estípulas cedo decíduas. Folhas com pecíolo ca $4 \mathrm{~cm}$ compr., um par de glândulas sésseis oblato ou oval, dispostas no ápice do pecíolo; lâminas membranáceas, palmadas, 5-lobadas, lobos oblongo-lanceolados, ca. 8,7 × 9,5 cm, ca. $7,1 \times 3 \mathrm{~cm}(\mathrm{~lm}), 6-6,3 \times 2,5-2,6 \mathrm{~cm}$ (lobo lateral central), ca. 3,5 × 1,7 cm (lobo lateral marginal), ângulo divergente $65^{\circ}-81^{\circ}(\mathrm{lm} \times 11$ marginal $)$, ápice acuminado, apiculado, base cordada, margem serreada a glandular-serreada, oceolos ausentes, 2 glândulas no sino dos lobos. Mônades, pedunculadas; pedúnculo 1,5-2 $\mathrm{cm}$ compr. Brácteas ca. 1,1 $\times 2 \mathrm{~cm}$ compr., verticiladas, ovadaespatuladas, margem serreada, cedo decíduas. Flores brancas; pedicelos 3-4 mm compr.; sépalas ca. $2,7 \times 1,1-1,3 \mathrm{~cm}$, ápice obtuso, dorso com arista 3-4 mm compr., subcoriáceas, face abaxial verde; pétalas ca. 2,5 ×0,7 cm, ápice obtuso; corona com múltiplas séries, bandeadas de azul e branco, filamentos brancos e azuis a vináceos, os externos 

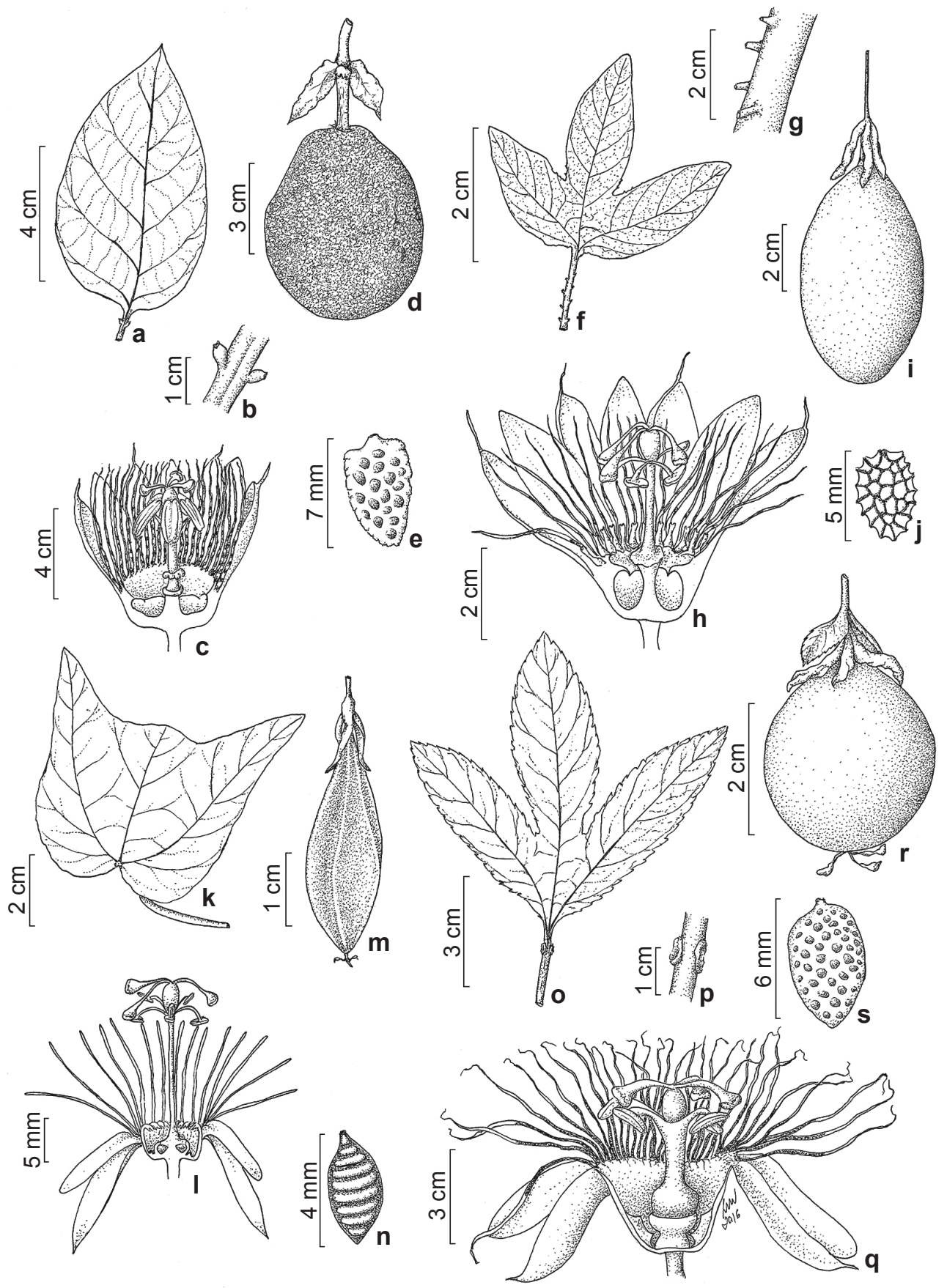

Figura 9 - a-e. Passiflora alata - a. folha; b. detalhe do pecíolo com glândula; c. corte longitudinal da flor; d. fruto; e. semente. f-j. Passiflora amethystina - f. folha; g. detalhe do pecíolo com glândula; h. corte longitudinal da flor; i. fruto; j. semente. k-n. Passiflora capsularis -k. folha; 1 . corte longitudinal da flor; $\mathrm{m}$. fruto; $\mathrm{n}$. semente. o-s. Passiflora edulis - o. folha; p. detalhe do pecíolo com glândula; q. corte longitudinal da flor; r. fruto; s. semente. Desenhado por Luiz Menini Neto. (a-d. A.M. Moraes 305; e. A.M. Moraes 289; f-h. A.M. Moraes 286; i. A.M. Moraes 336; j. M.F. Vieira 799; k. A.M. Moraes 348; 1-n. A.M. Moraes et al. 337; o,p,r,s. A.M. Moraes 309; q. F.R.G. Salimena \& P.H. Nobre 2841).

Figure 9 - a-e. Passiflora alata - a. leaf; b. detail of the petiole with gland; c. longitudinal cut of the flower; d. fruit; e. seed. f-j. Passiflora amethystina - f. leaf; g. detail of the petiole with glands; h. longitudinal cut of the flower; i. fruit; j. seed. k-n. Passiflora capsularis - k. folha; 1. longitudinal cut of the flower; $\mathrm{m}$. fruit; $\mathrm{n}$. seed. o-s. Passiflora edulis - o. folha; $\mathrm{p}$. detail of the petiole with gland; $\mathrm{q}$. longitudinal cut of the flower; r. fruit; s. seed. Drawn by Luiz Menini Neto. (a-d. A.M. Moraes 305; e. A.M. Moraes 289; f-h. A.M. Moraes 286; i. A.M. Moraes 336; j. M.F. Vieira 799; k. A.M. Moraes 348; 1-n. A.M. Moraes et al. 337; o,p,r,s. A.M. Moraes 309; q. F.R.G. Salimena \& P.H. Nobre 2841). 
1,5-2 cm compr., duas séries, livres, filiformes, ápice acirular, os internos 1-10 mm compr., duas séries, filiformes, ápice agudo, e inúmeras séries internas reduzidas $0,5-10 \mathrm{~mm}$ compr., subulados e eretos; opérculo ca. $4 \mathrm{~mm}$ compr., ápice filamentoso, parte inferior membranosa; límen cupuliforme; coluna do androginóforo ca. $1,3 \mathrm{~cm}$ compr.; presença de um anel nectarífero anular; filetes ca. $8 \mathrm{~mm}$ compr., anteras $8-9 \times 4-5 \mathrm{~mm}$; ovário 3,5-4 × ca. $34 \mathrm{~mm}$, globoso, tomentoso; estiletes $10-11 \mathrm{~mm}$ compr. Frutos bagas 3,5-5 $\times 2,5-5,5 \mathrm{~cm}$, verdes a amarelados com máculas verde-claro, alaranjados quando secos, globosos, pubérulos a esparsos. Sementes $8-9 \times 7-8 \mathrm{~mm}$, obcordadas, achatadas com margem alada, ápice com mais de um corno, base cordada a truncada, testa finamente reticulada.

Material examinado: Araponga, PESB, Fazenda Brigadeiro, trilha Matipó, 23.XII.2014, fl. e fr., A.M. Moraes et al. 313 (CESJ); 14.I.2015, fr., A.M. Moraes et al. 325 (CESJ).

Material complementar: BRASIL. ESPÍRITO SANTO: Nova Venécia, 4.IX.1960, fr., A.P. Duarte 3711 (RB); 4.IX.1960, fr., A.P. Duarte 94494 (RB). RIO DE JANEIRO: Santa Maria Madalena, 3.VII.1960, bot., A.P. Duarte 14242 (RB).

Passiflora filamentosa é endêmica do Brasil e da Floresta Atlântica. Distribui-se nos estados de Minas Gerais, Espírito Santo, Rio de Janeiro e Bahia (BFG 2015; SpeciesLink 2017. Disponível em $<$ http://inct.splink.org.br/>). Ocorre em Floresta Ombrófila, borda e interior da floresta. Frequente na orla de florestas, e quando se encontra no interior desenvolve seus ramos até atingirem

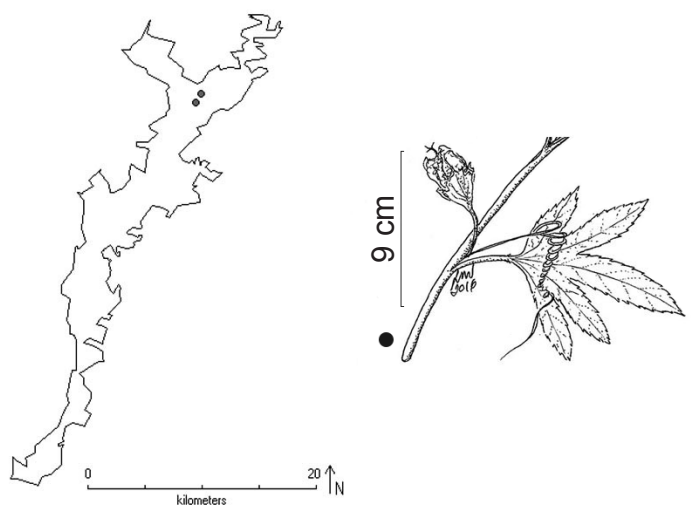

Figura 10 - Distribuição de Passiflora filamentosa no Parque Estadual da Serra do Brigadeiro, MG. Desenhado por Luiz Menini Neto.

Figure 10 - Distribution of Passiflora filamentosa in the Serra do Brigadeiro State Park, MG. Drawn by Luiz Menini Neto. a copa das árvores (Cervi 1997). Foi encontrada somente na região norte do PESB, na Fazenda Brigadeiro, município de Araponga, em Floresta Ombrófila Densa em mata fechada sobre árvores com mais de dez metros de altura, impossibilitando a visualização do indivíduo inteiro.

A espécie Passiflora filamentosa apresenta registros de ocorrência restritos a poucos locais nos estados de Minas Gerais, Rio de Janeiro, Espírito Santo e Bahia. Sua última coleta em Minas Gerais foi em 1925, na Serra do Grama, região da Serra do Brigadeiro, e está depositada no Herbário MO (SpeciesLink 2015. Disponível em $<$ http://inct.splink.org.br/>). De acordo com Bernacci et al. (2005) P. filamentosa é uma espécie pouco conhecida, e poderia ser categorizada como Ameaçada de Extinção ou Extinta no Brasil, devido à um longo período com falta de registros para esta espécie. Porém novos registros de ocorrência foram encontrados no decorrer dos anos de acordo com a banco de dados online SpeciesLink (2017) para os estados do Rio de Janeiro e Espírito Santo. Já em Minas Gerais, esta espécie ocorre exclusivamente no Parque Estadual da Serra do Brigadeiro, o que ressalta a extrema importância do monitoramento e estudos dessa espécie para sua conservação.

No PESB foi coletada com flor em dezembro e com fruto em dezembro e janeiro. Devido ao seu hábito escandente, pode atingir a copa de árvores muito altas, o que pode contribuir com o reduzido número de coletas. Foram encontrados no solo vários frutos predados e com marcas de dentes incisivos, provavelmente de primatas do gênero Callithrix (Erxleben 1777) (Comunicação pessoal do Dr. Carlos Ramon Ruiz-Miranda da Universidade Estadual do Norte Fluminense Darcy Ribeiro (UENF)).

As estípulas não foram encontradas no material complementar para descrição, porém de acordo com Killip (1938), estas são dolabriformes com a margem serreada, ápice aristado, cedo decíduas. Como citado anteriormente, Passiflora filamentosa se assemelha mais a $P$. edulis.

Pode ser identificada pelo hábito lenhoso, folhas pentalobadas, estípulas com 1 par de glândulas sésseis na base da lâmina foliar, brácteas ovado-espatuladas com margens serreadas, flores brancas com filamentos, corona com múltiplas séries, bandeadas de azul e branco, e presença de anel nectarífero anular. Os frutos são verdes a alaranjados quando secos, com máculas e sementes obcordadas com margem alada. 
6. Passiflora mediterranea Vell., Fl. Flumin. Icon. 9: t.72, 1825.

Figs. $11 ; 13 f-j$

Trepadeiras escandentes, herbáceas, glabras. Caule cilíndrico, estriado, verde, castanho à vináceo. Estípulas 9-50 × 4-20 mm compr., semi-ovada ou subreniformes, ápice acuminado à aristado, arista 1-3 mm compr., base arredondada, margem inteira. Folhas com pecíolo 1,2-3,8 cm compr., 1-4 pares ou 8 glândulas dispersas, tubulares, dispostas 2-20 mm compr. da base, pedunculadas; lâminas foliares coriáceas à cartáceas, inteiras, ovadolanceoladas a oblongo-lanceoladas, 5,2-16,5 × 2,1-6,3 cm, ápice agudo a obtuso, apiculado, base arredondada a cordada, subpeltada, margem inteira a glandular-serreada, com até 6 glândulas em uma das margem, oceolos ausentes, face adaxial lustrosa com 5 nervuras hialinocartilaginosas, face abaxial raramente esparsa. Mônades ou díades, pedunculadas; pedúnculos 2,7-6,6 cm compr., axilares aos pares. Brácteas $0,9-2,5 \times 0,5-1,3$ $\mathrm{cm}$ compr., verticilada, ovado-lanceolado a oval, persistente. Flores alvas a levemente esverdeadas; pedicelos 2-6 mm compr.; sépalas 1,3-2,2 × 0,4-0,8 $\mathrm{cm}$, ápice obtuso, dorso com arista $1-2 \mathrm{~mm}$ compr.; pétalas 1,3-2,2 × 0,4-0,7 cm, ápice obtuso; corona tri ou tetrasseriada, base alva, ápice alvo, filamentos alvos, os externos $0,7-1,4 \mathrm{~cm}$ compr., livres, filiformes, ápice linear a agudo, os internos $1-3 \mathrm{~mm}$ compr., filiformes, ápice capitado a arredondado; opérculo 2-3 mm compr., membranoso, encurvado, ápice serrado ou lacerado; límen cupuliforme, rodeando frouxamente o androginóforo; coluna do androginóforo $0,7-1 \mathrm{~cm}$ compr., esverdeado a rosado; filetes 5-7 mm compr., anteras 4-6,5 $\times 1-2$ $\mathrm{mm}$; ovário 3-6 6 1-3 mm, ovoide, glabro; estiletes 6-10 mm compr. Frutos bagas 1,3-2,5 $\times 0,6-1,3 \mathrm{~cm}$, amarelo a esverdeado, ovoide, glabros. Sementes 3-4 × 1,5-2,5 mm, cuneado-oblongas, ápice com um corno, base aguda, testa retículo-alveolada. Material examinado: Araponga, PESB, 1.I.2008, fl., V.S. Moura et al. 74 (HUEMG); Estouro, 13.II.1985, bot. e fr., W.N. Vidal et al.704 (VIC); Fazenda Brigadeiro, Trilha Matipó e Lage D’Ouro, 23.XII.2014, bot., fl. e fr., A.M. Moraes 312 (CESJ); Serra das Duas Cabeças, 29.IV.2015, bot. e fl., A.M. Moraes \& A.M. Moraes 359 (CESJ). Carangola, PESB, 24.IV.1991, fl., L.S. Leoni \& C. Medeiros 19547 (UPCB); 10.I.2008, fl., V.S. Moura et al. 74 (HUEMG). Fervedouro, PESB, Pedra do Pato, 23.XII.2014, bot., A.M. Moraes 310 (CESJ); Pico do Grama, Serra do Grama, 29.I.2003, fl. e fr., G.E. Valente et al. 1123 (VIC); 24.XII.2014, bot. e fr., A.M. Moraes 319 (CESJ). Miradouro, PESB, Serra do Tabuleiro, 26.II.2015, fr., A.M. Moraes \& L.P. Gurgel 352 (CESJ). Pedra Bonita, PESB, Fazenda Brigadeiro, 15.I.2015, bot., fl. e fr., A.M. Moraes et al. 327 (CESJ).
Passiflora mediterranea é endêmica do Brasil e do domínio Atlântico. Distribui-se em toda a Região Sudeste e no Sul, nos estados do Paraná e Santa Catarina (BFG 2015). Ocorre em Florestas Ombrófilas, sendo comum em florestas de encosta, se estendendo sobre árvores altas. Também se desenvolvem na borda de florestas, capoeiras e capoeirões e em vegetação de restinga (Cervi 1997). No PESB ocorre com elevada abundância (Fig. 11), principalmente em áreas com grande exposição à luminosidade, clareiras, campos de altitude arbustivo, vegetação em estágio inicial de regeneração e áreas abertas com vegetação arbustiva e árvores de pequeno a médio porte (máximo 5-6 $\mathrm{m}$ altura).

No PESB floresce e frutifica de outubro a fevereiro. A forma de suas folhas e estruturas dos ramos é muito semelhante às de Passiflora miersii, fazendo com que sejam confundidas. Porém, $P$. miersii se distingue por possuir a face abaxial das folhas roxa, textura membranácea a subcoriácea e estípulas com margem crenada. Suas flores foram observadas constantemente sendo visitada por insetos, provavelmente coleópteros.

Pode ser identificada por ser uma trepadeira glabra, com hábito escandente, estípulas subreniformes com ápice aristado, lâminas foliares inteiras cartáceas a coriáceas, ovado-lanceoladas a oblongo-lanceoladas, com ápice agudo, face adaxial lustrosa com 5 nervuras hialinocartilaginosas, flores brancas, com corona de filamentos branca tri ou tetrasseriada e frutos ovoides, amarelos a esverdeados.
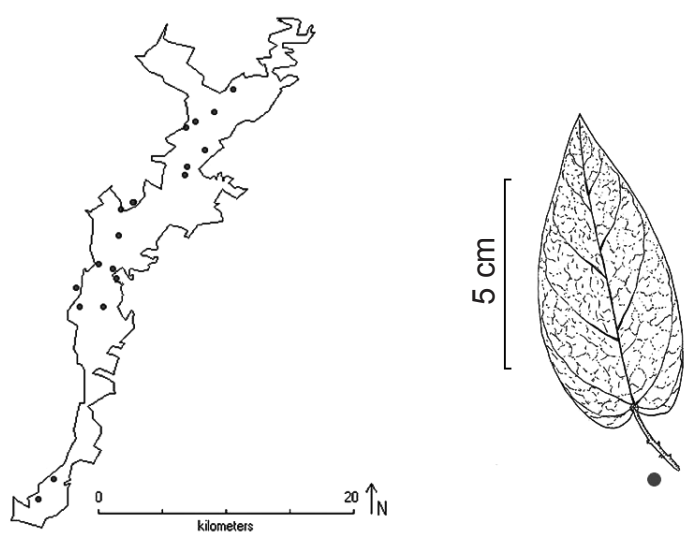

Figura 11 - Distribuição de Passiflora mediterranea no Parque Estadual da Serra do Brigadeiro, MG. Desenhado por Luiz Menini Neto.

Figure 11 - Distribution of Passiflora mediterranea in the Serra do Brigadeiro State Park, MG. Drawn by Luiz Menini Neto. 
7. Passiflora miersii Mart., Fl. brasiliensis 13(1): 561, 599. 1872.

Figs. 12; 13k-n

Trepadeiras escandentes, herbáceas, glabras. Caule cilíndrico, levemente estriado. Estípulas 8-15 × 4-6 mm, semi-ovadas, ápice mucronado ou aristado, arista 1,5-2 mm compr., margem crenada. Gavinhas avermelhadas. Folhas com pecíolos 1,3-2,2 cm compr., roxo-avermelhado, um par de glândulas estipadas, dispostas $10-18 \mathrm{~mm}$ compr. da base, pedunculadas; lâminas foliares subcoriáceas a membranáceas, inteiras, ovado-lanceoladas, 4,5-6,2 × 1,8-2,8 cm, ápice agudo a obtuso, base arredondada, subpeltada, margem inteira, oceolos ausentes, 3-5 nervuras subcoriáceas avermelhadas, face abaxial roxa a levemente avermelhada. Mônades, pedunculadas; pedúnculos 2,8-3 cm compr. Brácteas 0,4-0,6 × 0,2-0,3 cm compr., alternas, ovado-lanceoladas a ovais, cedo caducas. Flores brancas; pedicelos 3-4 mm compr.; sépalas $1,8-2,3 \times 0,5-0,57 \mathrm{~cm}$, ápice obtuso, arista no dorso 1,5-3 mm compr.; pétalas 2,3-2,5 ×0,4-0,45, ápice obtuso; corona tetrasseriada, base roxo-escura, ápice alvo, filamentos púrpura à violeta, duas séries externas 1,6-1,9 cm compr., livres, filiformes, ápice filiforme, bandeados de branco e púrpura, os internos 5-15 mm compr., terceira série linear, violeta, quarta série ereta, bandeado de violeta e purpura, ápice denticulado a subulado; opérculo 4-5 mm compr., membranoso, ereto na base, levemente inclinado para o androginóforo, com uma linha de filamentos na face exterior, ápice filamentoso; límen cupuliforme, envolvendo frouxamente o androginóforo; coluna do androginóforo 1,43-1,55 cm compr.; filetes 10,4-11 mm compr., anteras 7-8,4 × 2-2,4 cm; ovário 5,9-6 × 2,8-3 mm, ovoide, glabro; estiletes $6-8 \mathrm{~mm}$ compr. Frutos bagas ca. 3,2 $\times 1,4 \mathrm{~cm}$, verdes, lanceolados, glabros. Sementes, obovadas, testa reticulada.

Material examinado: Araponga, PESB, Pico do Boné, Vale das Luas, 16.I.2015, bot., A.M. Moraes et al. 330 (CESJ).

Material complementar: BRASIL. MINAS GERAIS: Juiz de Fora, 8.II.2003, fr., D.S. Pifano et al. 518 (CESJ). Ritápolis, 23.III.2011, fl., M. Sobral et al. 14053 (RB). São Roque de Minas, 20.IV.1997, fl., J.N. Nakajima et al. 2413 (RB).

Passiflora miersii é uma espécie endêmica do Brasil e ocorre no estado do Paraná, na Região Sudeste, e nos estados da Bahia, Sergipe, Distrito Federal e Mato Grosso do Sul. Está presente nos domínios da Caatinga, Cerrado e Floresta Atlântica. Ocorre em Floresta Estacional Semidecidual, Cerrado sensu stricto, em áreas antrópicas, na borda de matas e em capoeirões (Cervi 1997; BFG 2015). No PESB foi coletada em um único ponto no munícipio de Araponga, em vegetação de regeneração, próximo a pastagens e exposta ao sol, em área de Zona de Amortecimento.

A espécie Passiflora miersii foi encontrada apenas na área de entorno zona de amortecimento, na trilha para o Pico do Boné, e não havia nenhum outro material da espécie depositado em herbários até o momento, apesar do Plano de Manejo (2006) citar a ocorrência da mesma no Parque, da mesma forma que Leoni \& Tinte (2004), ocorrendo em área de transição.

Foi coletada com botões florais em janeiro. $\mathrm{Na}$ área de estudo se assemelha a Passiflora mediterranea na forma das folhas e ramos. No entanto, pode ser identificada pelas folhas inteiras ovado-lanceoladas, membranáceas a subcoriáceas, estípulas semi-ovadas com margens crenadas, flores brancas com corona tetrasseriada, branca e púrpura à violeta.

8. Passiflora porophylla Vell., Fl. Flum. 9: t.82. 1827.

Figs. $14 ; 15 ; 21 \mathrm{a}-\mathrm{d}$ Trepadeiras com indumento pubérulo nos ramos, caules, gavinhas, estípulas, pecíolos, pedúnculos, pedicelos, brácteas, hipantos, sépalas, ovários e frutos; face abaxial das lâminas foliares, face adaxial das lâminas foliares pubérulo a glabra, tricomas falcados a subulados, unicelulares, adpressos ou não. Caule subtriangular, estriado. Estípulas 1,5-4 × 0,5 mm, subuladas-falcadas. Folhas com pecíolos 2-3,8 cm compr., glândulas

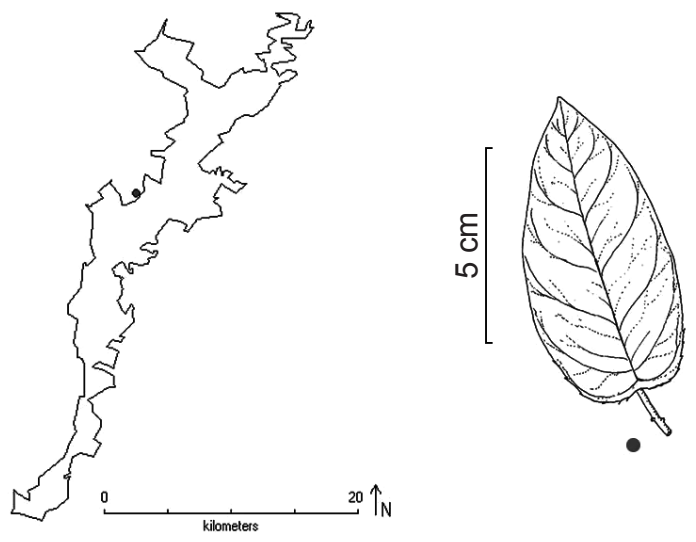

Figura 12 - Distribuição de Passiflora miersii no Parque Estadual da Serra do Brigadeiro, MG. Desenhado por Luiz Menini Neto.

Figure 12 - Distribution of Passiflora miersii in the Serra do Brigadeiro State Park, MG. Drawn by Luiz Menini Neto. 

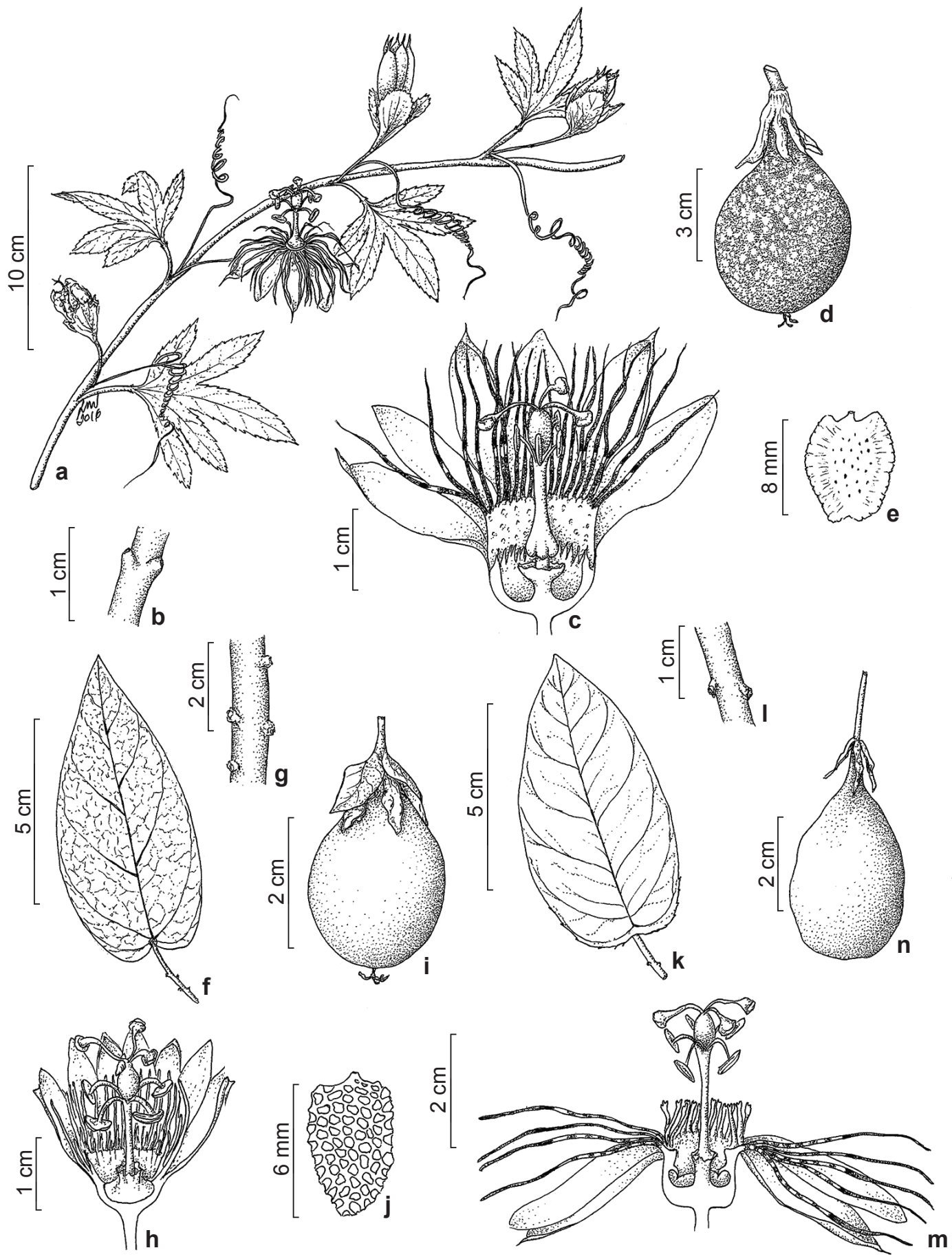

Figura 13 - a-e. Passiflora filamentosa - a. ramo; b. detalhe do pecíolo com glândula; c. corte longitudinal da flor; d. fruto; e. semente. f-j. Passiflora mediterranea -f. folha; g. detalhe do pecíolo com glândula; h. corte longitudinal da flor; i. fruto; j. semente. k-n. Passiflora miersii - k. folha; 1. detalhe do pecíolo com glândula; m. corte longitudinal da flor; n. fruto. Desenhado por Luiz Menini Neto. (a. A.C. Duarte 3711, 94494 - RB; b-e. A.M. Moraes et al. 313; f-j. A.M. Moraes et al. 307; k,1. A.M. Moraes et al. 330; m. M. Sobral et al. 14053; n. D.S. Pifano et al. 518).

Figure 13 - a-e. Passiflora filamentosa - a. branch; b. detail of the petiole with glands; c. longitudinal cut of the flower; d. fruit; e. seed. f-j. Passiflora mediterranea - f. leaf; g. detail of the petiole with gland; h. longitudinal cut of the flower; i. fruit; j. seed. k-n. Passiflora miersii - k. leaf; 1 . detail of the petiole with gland; $\mathrm{m}$. longitudinal cut of the flower; $\mathrm{n}$. fruit. Drawn by Luiz Menini Neto. (a. A.C. Duarte 3711, 94494 - RB; b-e. A.M. Moraes et al. 313; f-j. A.M. Moraes et al. 307; k,1. A.M. Moraes et al. 330; m. M. Sobral et al. 14053; n. D.S. Pifano et al. 518). 
ausentes; lâminas foliares membranáceas à cartáceas, bilobadas, lobos lanceolados a obovado, podendo ocorrer o lobo médio um pouco mais proeminente, $2,4-7,5 \times 4,5-10,4 \mathrm{~cm}$., $1,5-4,7$ $\times 1,2-2,6 \mathrm{~cm}$ (11), ângulo divergente $32^{\circ}-56^{\circ}$, ápice agudo, obtuso a arredondado, base obtusa a arredondada, subpeltada, margem inteira, oceolos presentes, 7-20 oceolos dispostos entre as nervuras principais dos lobos, face adaxial pubérulo a glabra, variegada com máculas verde claro ou não, face abaxial verde a roxa. Mônades, pedunculadas; pedúnculos 1,8-5,5 cm compr. Brácteas $1-5 \times$ ca. $0,5 \mathrm{~mm}$, alternas, linear-subuladas. Flores brancoesverdeadas, verdes ou roxo-escuro; pedicelos 2-3 mm compr.; sépalas $1,1-1,7 \times 0,5-0,6 \mathrm{~cm}$, ápice obtuso; pétalas ca. $1 \times 0,35-0,45 \mathrm{~cm}$; corona unisseriada, base roxa, ápice alvo, filamentos bandeado de roxo e alvo, 7-8 × 1-1,1 mm, livres, dolabriformes, ápice cuneiforme; opérculo 3-3,5 $\mathrm{mm}$ compr., plicado, ápice introrsamente curvo; límen anelar; coluna do androginóforo $0,9-1 \mathrm{~cm}$ compr., roxo-escuro a vermelho-escuro; filetes 5-6 mm compr. roxo-escuro, anteras 3,5-4 $\times$ 0,5-2 mm; ovário $2-3 \times 2-2,5 \mathrm{~mm}$, globoso, denso pubérulo; estiletes $5-7 \mathrm{~mm}$ compr. Frutos bagas $0,7-2,3 \times 0,6-2 \mathrm{~cm}$, verdes, globosos, denso pubérulo. Sementes ca. $4 \times 2-3 \mathrm{~mm}$, obovadas, ápice com corno ausente, base aguda, testa sulcada transversalmente.

Material examinado: Araponga, PESB, Estouro, 4.IV.1986, fl., M.F. Vieira et al. 355 (UPCB, VIC); Serra das Duas Cabeças, 29.IV.2015, fr., A.M. Moraes et al. 358 (CESJ); trilha do Carvão, Região do Boné, 17.I.2015, bot., fl. e fr., A.M. Moraes et a.l 340 (CESJ). Fervedouro, PESB, estrada Fervedouro-Araponga, 18.I.2015, bot. e fl., A.M. Moraes et al. 346 (CESJ).

Passiflora porophylla é endêmica do Brasil, ocorrendo nas regiões Sudeste e Sul, além do estado da Bahia. Está presente no Cerrado e Floresta Atlântica, em vegetação de cerrado lato sensu, Floresta Estacional Semidecidual e Floresta Ombrófila Montana e Submontana (Milwardde-Azevedo et al. 2012; BFG 2015). Ocorre preferencialmente em capoeiras, beiras de estradas e bordas de florestas, raramente no interior (Sacco 1980). E distribui-se também na Serra do Caparaó, Serra da Mantiqueira e do Mar e arredores da Serra do Espinhaço (Milward-de-Azevedo \& Baumgratz 2004). No PESB foi encontrada em diversos ambientes, como no interior de florestas, borda de trilhas e beira de estradas.

Floresce e frutifica em janeiro, com frutos também observados no mês de abril. As folhas possuem grande plasticidade quanto à forma,

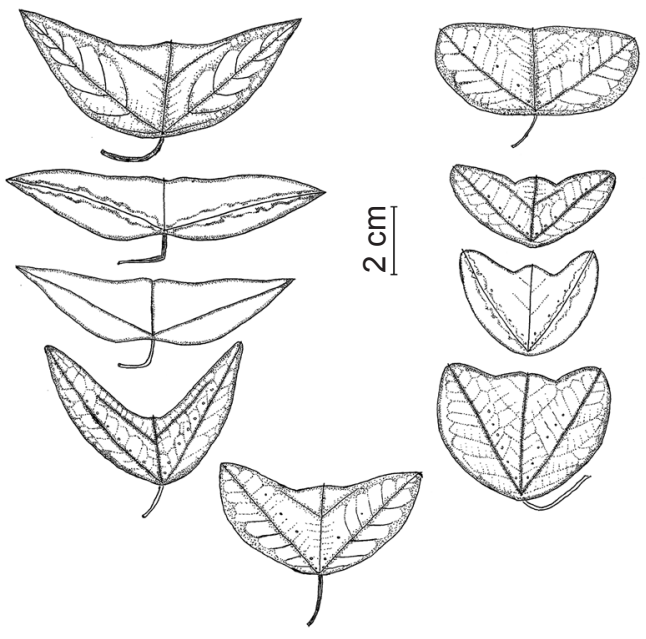

Figura 14 - Variação morfológica das folhas de Passiflora porophylla. Desenhado por Andreza M. Moraes.

Figure 14 - Morphological variation of the leaf of Passiflora porophylla. Drawn by Andreza M. Moraes.

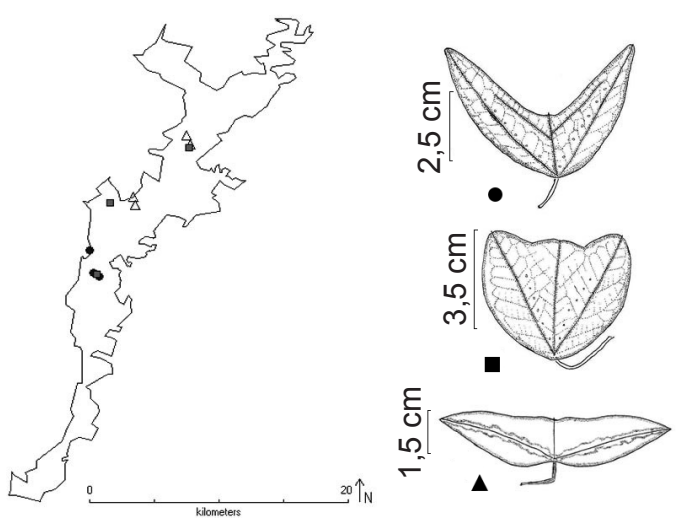

Figura 15 - Distribuição de Passiflora porophylla no Parque Estadual da Serra do Brigadeiro, MG. Desenhado por Andreza M. Moraes.

Figure 15 - Distribution of Passiflora porophylla in the Serra do Brigadeiro State Park, MG. Drawn by Andreza M. Moraes.

com espécimes de lâminas foliares 2-lobadas de lobos com ápice arredondado $(\bullet)$, obtuso (ロ) ou agudo $(\boldsymbol{\Delta})$, além de ângulos divergentes variados e folhas variegadas ou não (Figs. 14; 15). A distribuição destas formas não demonstrou um padrão determinado, ocorrendo simultaneamente nas áreas (Fig. 15). Assim, estas características podem estar sendo influenciadas por fatores como solo e luminosidade. 
Conforme citado anteriormente, Passiflora capsularis e $P$. porophylla possuem características semelhantes, podendo ser confundidas na área de estudo. A espécie pode ser identificada no campo pelas folhas bilobadas, com máculas ou não, face abaxial da lâmina foliar verde a roxas e oceolos presentes. Pecíolo com glândulas ausentes, estípulas subulada-falcadas, flores roxas com corona unisseriada, filamentos dolabriformes com ápice cuneiforme e fruto pubescente com semente com testa sulcada transversalmente.

9. Passiflora rhamnifolia Mast., Fl. brasiliensis 13(1): 545, 575. 1872.

Figs. 16; 21e-i

Trepadeira escandente, lenhosa, com gavinhas cedo caducas, glabra a esparso na face adaxial da lâmina foliar, caule pubérulo, esparso a pubescente no pecíolo, gavinhas, estípulas, face abaxial das lâminas foliares, nervuras foliares, pedúnculo, pedicelo, brácteas, hipanto, sépalas, fruto, tomentoso no ovário e denso pubescente nas nervuras principais da lâmina foliar; tricomas filiformes e subulados, unicelulares, adpressos ou não. Caule cilíndrico, estriado. Estípulas 0,5-9,5 mm compr., subuladas, cedo caducas. Folhas com pecíolos 1,8-4,3 cm compr., um par de glândulas ovoides a lanceoladas, dispostas no ápice do pecíolo, sésseis; lâminas foliares membranáceas a coriáceas, inteiras, ovadolanceoladas a ovado-oblongas, 8,5-14 ×4,5-7,5 cm, ápice agudo, base arredondada a cuneada, margem inteira, oceolos ausentes. Mônades, pedunculadas; pedúnculos 1,2-1,3 cm compr. Brácteas 1,5-3× 1-2 mm compr., alternas, linear-subuladas, cedo caducas. Flores brancas a amarelas; pedicelos ca. $9 \mathrm{~mm}$ compr.; sépalas $1,7-1,8 \times$ ca. $0,4 \mathrm{~cm}$, ápice obtuso; pétalas ca. $2,3 \times 0,4 \mathrm{~cm}$, ápice obtuso; corona bisseriada, base alva, ápice amarelo com máculas vináceas, filamentos amarelos, os externos 1,3-1,5 cm compr., livres, subdolabriformes, ápice dilatado, base linear, os internos $2-3 \mathrm{~mm}$ compr., filiformes, ápice dilatados; opérculo ca. 3 $\mathrm{mm}$ compr., recurvado, ápice filamentoso; límen ausente; coluna do androginóforo 1,5-1,8 cm compr.; presença de um anel nectarífero; filetes ca. $5 \mathrm{~mm}$ compr., anteras ca. $5 \times 1-2 \mathrm{~mm}$; ovário ca. 4 $\times 1,5-2 \mathrm{~mm}$, ovoide, sulcado, tomentoso; estiletes ca. $9 \mathrm{~mm}$ compr. Frutos bagas $4-5 \times 2,5-3,5$ $\mathrm{cm}$, amarelos e esverdeados, sulcado (6-partida), elípticos, pubescentes. Sementes 7-9 × 4-5 mm, obovadas, ápice com um corno, base aguda, testa reticulo-foveada.

Material examinado: Araponga, PESB, Pico do Boné, 1.XI.2014, fr., A.M. Moraes et al. 302 (CESJ). Pedra
Bonita, PESB, Fazenda Brigadeiro, 16.I.2015, fr., A.M. Moraes et al. 363 (CESJ).

Material complementar: BRASIL. ESPÍRITO SANTO: Castelo, 13.II.2008, fl., L. Kollmann et al. 10598 (RB). Linhares, 7.XI.2012, fl., G.S. Siqueira 818 (RB). MINAS GERAIS: Juiz de Fora, 26.II.2008, fl., N.M. Farinazzo et al. 2 (CESJ).

Passiflora rhamnifolia é endêmica do Brasil, ocorrendo em áreas de Floresta Atlântica nos estados da Bahia e na Região Sudeste, em Floresta Ombrófila e Floresta Estacional Decidual (Cervi et al. 2009; Hilgenhof 2012; BFG 2015). No PESB, foi encontrada no interior de Floresta Ombrófila somente na porção norte da UC, nos municípios de Araponga e Pedra Bonita, e na região do Boné e Fazenda Brigadeiro.

No PESB foi coletada com fruto em novembro. Apresenta hábito lenhoso e caule com cerca de $5 \mathrm{~cm}$ de diâmetro. Pode ser identificada pelo hábito lenhoso, folhas inteiras pubescentes, com um par de glândulas sésseis na base da lâmina foliar, flores brancas com corona de filamentos amarelos subdolabriformes, ovário sulcado e fruto sulcado (6-partido), elíptico e pubescente.

10. Passiflora speciosa Gardner, Fielding and Gardn. Sert. Pl. pl. 17. 1844.

Figs. 17; 18; 19; 210-s

Trepadeira lenhosa, tomentosa-ferrugínea no caule, gavinhas, estipulas, pecíolos pedúnculo e pedicelo, pubescente na face adaxial e abaxial da lâmina foliar, brácteas, pétalas, sépalas, hipanto e fruto com tricomas subulado-falcado, unicelular,
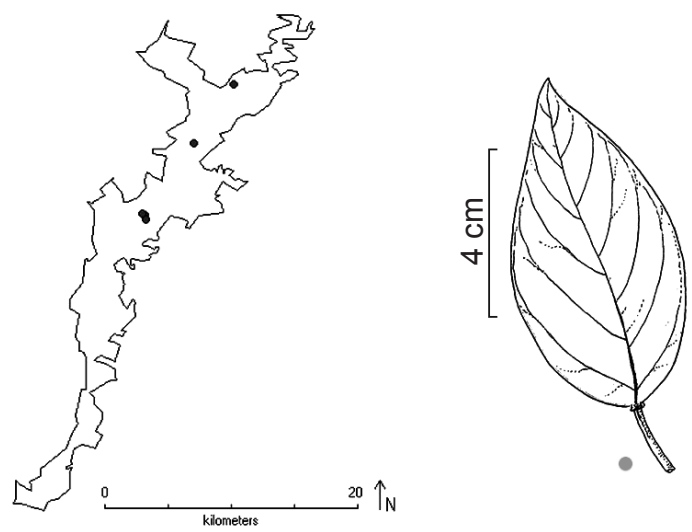

Figura 16 - Distribuição de Passiflora rhamnifolia no Parque Estadual da Serra do Brigadeiro, MG. Desenhado por Luiz Menini Neto.

Figure 16 - Distribution of Passiflora rhamnifolia in the Serra do Brigadeiro State Park, MG. Drawn by Luiz Menini Neto. 
raramente estrelado, adpresso ou não. Caule cilíndrico estriado e sulcado. Estípulas setáceasfalcadas 3-10 $\mathrm{mm}$ compr. Folhas com pecíolo 0,8-5 cm compr., um par de glândulas sésseis na base, cupuliforme a oblato, às vezes 1-3 glândulas pedunculadas, urceoladas, dispostas a 8-16 mm da base; lâminas foliares cartáceas a membranáceas, pouco frequentemente inteiras, ovada-lanceoladas, 2-18, $1 \times 1-4,3 \mathrm{~cm}$, ou 3-lobadas, lobos oblongolanceoladas, linear-lanceolado a assimétricas, $3,2-18,5 \times 3,5-14,2 \mathrm{~cm}, 3,9-14,5 \times 1,1-3,5 \mathrm{~cm}$ (lm), 2-9,5 × 0,6-2,8 cm (11), ângulo divergente $20^{\circ}-50^{\circ}$, ápice agudo a obtuso-acuminado, base cordada a truncada, margem serreada ou duplamente serreado, ocelos ausentes, nervuras principais densamente pubescentes, 3-glândulas no sino dos lobos. Mônades, pedunculadas; pedúnculos 1,5-13 cm compr. Brácteas 1,5-4,2 × 0,6-1,8 cm, verticiladas, ovada-oblongas, margem serreada a glandular-serreada, persistentes. Flores rosa, rosa-escuro a avermelhadas, pedicelo $3-9 \mathrm{~cm}$ compr.; sépalas 4,2-6,1 × 0,5-1,3 cm, oblongas, ápice obtuso, com arista foliácea $2-6 \mathrm{~mm}$ compr.; pétalas 4,1-6 × 0,4-1,1 cm, oblongas, ápice obtuso; corona bisseriada, base alva, ápice vináceo, filamentos vináceos a alvos, externos $0,7-1 \mathrm{~cm}$ compr., livres, subulados, ápice arredondado a agudo, os internos 5-8 mm compr., ápice dentado; opérculo cupuliforme 4-6 mm compr., margem recurvada, ápice serrado ou erosa, límen rugoso, marrom esbranquiçado; coluna do androginóforo 2,2-3,5 cm compr., com estrias vináceas; filetes 6-15 mm compr.; anteras 8-15 × 1-3 mm; ovário 6-10 × 2-5 mm, ovoide, estrias e máculas ferrugíneas, viloso, com tricomas hirsuto e às vezes estrelado; estiletes $8-19 \mathrm{~mm}$ compr. Frutos bagas 2,7-6,5 × 1,3-4 cm, oblongos, velutinos, às vezes com tricomas estrelados, creme, acinzentado a esverdeado com listras e máculas vináceas a avermelhadas. Sementes 4-5 × 3-4 mm, obovadas, ápice com um corno, base arredondada, testa reticulo alveolada.

Material examinado: Araponga, PESB, 25.XI.2006, fr., E.J. Lucas et al. 691 (CESJ, ESA, IAC); Pedra do Pato, 16.X.2014, bot. e fl., A.M. Moraes \& M.A. Milward-de-Azevedo 297 (CESJ); Fazenda Brigadeiro, Trilha Matipó, 23.XII.2014, bot. e fl., A.M. Moraes \& A.M. Moraes 314 (CESJ); Pico do Boné, 16.I.2015, bot. e fl., A.M. Moraes et al. 333 (CESJ); sede, Trilha Pico do Grama, 15.X.2014, bot., fl. e fr., A.M. Moraes \& M.A. Milward-de-Azevedo 290 (CESJ); Serra D’Água, 20.XI.2004, bot. e fl., A.J.H. Salles 3431 (CESJ); Trilha do Carvão, 17.I.2015, bot. e fl., A.M. Moraes 341 (CESJ). Fervedouro, PESB, sede, Trilha do Muriqui e Encontro, 19.XII.1995, fr., L.A. Basilio et al. 15581 (VIC); 21.VIII.2014, bot. e fl., A.M. Moraes 285 (CESJ).

Passiflora speciosa é endêmica do Brasil, ocorrendo nas regiões Sudeste (estados do Rio de Janeiro, Espírito Santo e Minas Gerais), e Centro-Oeste (Longo 2002; BFG 2015). Nativa dos domínios Atlântico, Cerrado, Pantanal e Amazônico, está presente em Floresta Ombrófila e Florestas Estacionais Semideciduais, presente em bordas de florestas, capoeiras e capoeirões (Cervi \& Dunaiski-Junior 2004; BFG 2015). No PESB, $P$. speciosa foi frequentemente encontrada no interior de Floresta Ombrófila, no sub-bosque, em locais sombreados e às vezes com alta umidade, além das bordas das trilhas e de florestas (Fig. 18).

Floresce e frutifica de agosto a abril no PESB. E foram observados indivíduos constantemente em floração e frutificação (de agosto a abril) sendo visitados por beija-flores.

Passiflora speciosa apresentou grande plasticidade na morfologia foliar, com lâminas foliares 3-lobadas de ápice obtuso (ם) ou ápice agudo ( $\boldsymbol{\Delta})$ e lâminas inteiras ou assimétricas com

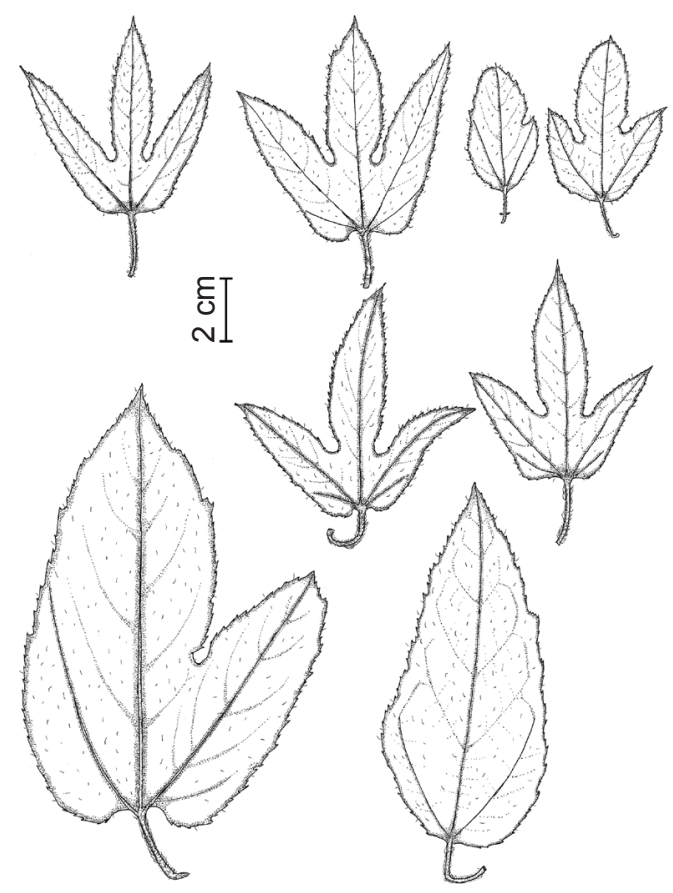

Figura 17 - Variação morfológica das folhas de Passiflora speciosa. Desenhado por Andreza M. Moraes.

Figure 17 - Morphological variation of the leaf of Passiflora speciosa. Drawn by Andreza M. Moraes. 
um, dois ou três lobos desenvolvidos (•) (Figs. 17; 18). O tipo mais comum foi o 3-lobado com ápice agudo $(\boldsymbol{\Delta})$, distribuído por toda a área de estudo de forma abundante. O tipo obtuso ( $\boldsymbol{\square}$ ) foi uma forma atípica restrita à sede do parque (A.M. Moraes 285) e o tipo inteiro/assimétrico (•) ocorreu somente na região norte em ambientes de Floresta Ombrófila no interior da floresta (Figs. 17; 18). A espécie também variou na disposição das glândulas, sendo que o tipo mais frequentemente encontrado possui um único par glândulas sésseis na base do pecíolo $(\bullet)$, sendo menos frequentes os morfotipos com um par de glândulas dispostas na porção peciolar e outro na base do pecíolo (घ) (Fig. 19). Todos os indivíduos com folhas assimétricas e inteiras possuem glândulas na porção peciolar. Foi observado na espécie um tronco lenhoso e subterrâneo com diâmetro de cerca de $5 \mathrm{~cm}$.

Passiflora speciosa pode ser identificada pelo hábito lenhoso, indumento tomentoso ferrugíneo, lâminas foliares inteiras a trilobadas de margem serreada com três glândulas no sino dos lobos, pecíolo com um par de glândulas sésseis na base, flores com pétalas e sépalas róseas, sépalas com arista foliácea e frutos oblongos, velutinos, acinzentados com máculas vináceas.

\section{Passiflora tetraden Vell., Fl. Flum. 9: t.91. 1825} [1829].

Figs. 20; 21j-n

Trepadeiras herbáceas, escandentes, glabra. Caule cilíndrico, estriado, verde-claro. Estípulas 9-23 × 6-18 mm compr., oblonga ou semi-ovadas, ápice agudo, com arista 0,2-1 $\mathrm{mm}$ compr., base

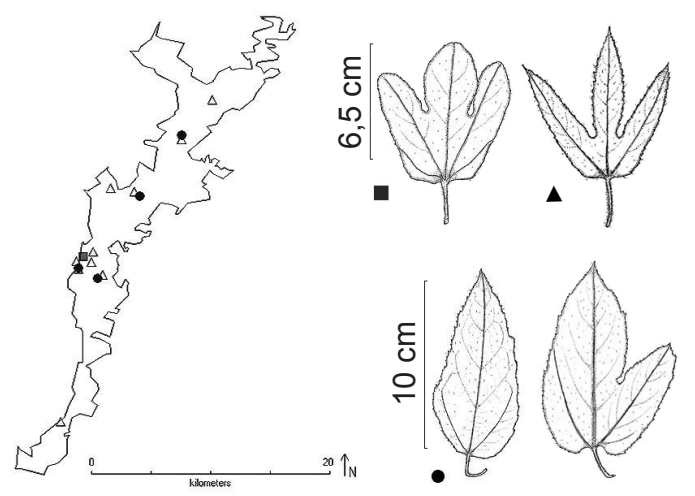

Figura 18 - Distribuição de Passiflora speciosa no Parque Estadual da Serra do Brigadeiro, MG. Desenhado por Andreza M. Moraes.

Figure 18 - Distribution of Passiflora speciosa in the Serra do Brigadeiro State Park, MG. Drawn by Andreza M. Moraes. arredondada. Folhas com pecíolo $1-4 \mathrm{~cm}$ compr., um a dois pares de glândulas no pecíolo, dispostas 7-15 mm compr. da base, pedunculadas; lâminas foliares membranáceas à subcoriácea, inteira, ovada, , ângulo divergente $14^{\circ}$ a $24^{\circ}$, ápice obtuso a arredondado, apiculado, ligeiramente 3-lobado para o ápice, com lobos laterais reduzidos e lobo médio mais proeminente, base arredondada, margem inteira, oceolos ausentes, face adaxial com 3 nervuras coriáceas proeminentes. Mônades,
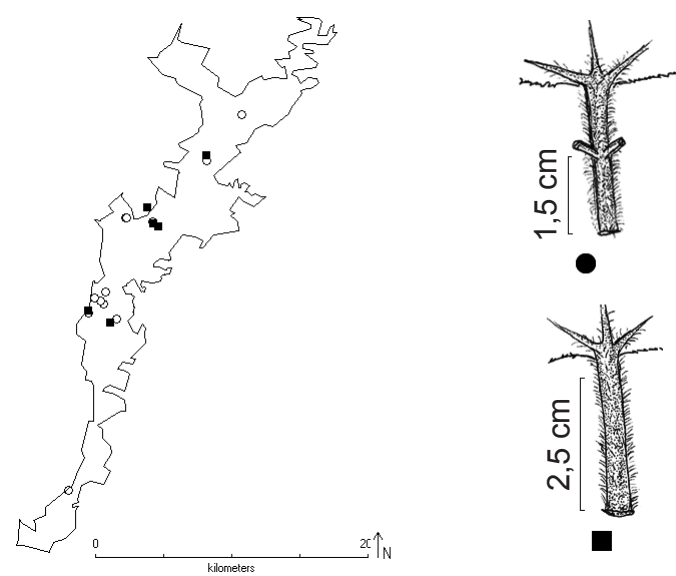

Figura 19 - Distribuição dos indivíduos de Passiflora speciosa pelo tipo de disposição de glândulas no Parque Estadual da Serra do Brigadeiro, MG. Desenhado por Andreza M. Moraes.

Figure 19 - Distribution of individuals of Passiflora speciosa by type of arranged of glands in the Serra do Brigadeiro State Park, MG. Drawn by Andreza M. Moraes.
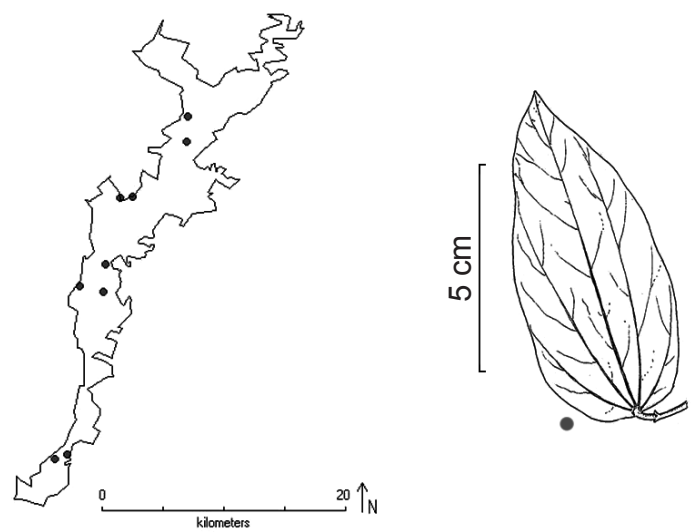

Figura 20 - Distribuição de Passiflora tetraden no Parque Estadual da Serra do Brigadeiro, MG. Desenhado por Luiz Menini Neto.

Figure 20 - Distribution of Passiflora tetraden in the Serra do Brigadeiro State Park, MG. Drawn by Luiz Menini Neto. 

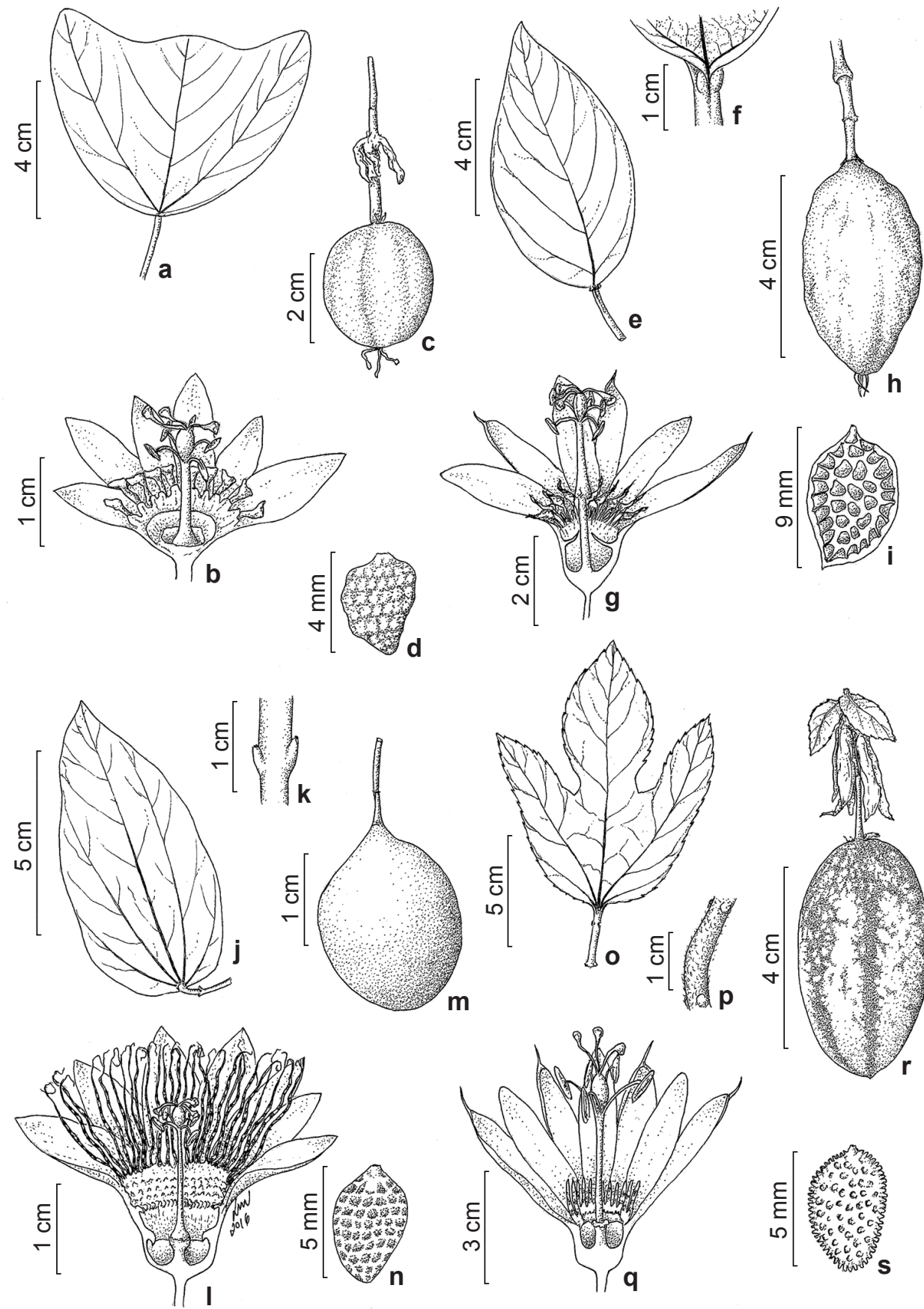

Figura 21 - a-d. Passiflora porophylla -a. folha; b. corte longitudinal da flor; c. fruto; d. semente. e-i. Passiflora rhamnifolia - e. folha; f. detalhe do pecíolo com glândula; g. corte longitudinal da flor; h. fruto; i. semente. j-n. Passiflora tetraden - j. folha; k. detalhe do pecíolo com glândula; 1 . corte longitudinal da flor; $m$. fruto; n. semente. o-s. Passiflora speciosa - o. folha; p. detalhe do pecíolo com glândula; q. corte longitudinal da flor; r. fruto; s. semente. Desenhado por Luiz Menini Neto. (a-d. A.M. Moraes et al. 340; e,f,h.A.M. Moraes et al. 302; g. N.M. Farinazzo et al. 2; i. A.M. Moraes et al. 302; j,k,1. A.M. Moraes \& A.P.G. Faria 288; m. A.M. Moraes et al. 322; n. Salimena 52859; p. A.M. Moraes et al. 299; o,q-s. A.M. Moraes 287). Figure 21 - a-d. Passiflora porophylla - a. leaf; b. longitudinal cut of the flower; c. fruit; d. seed. e-i. Passiflora rhamnifolia - e. leaf; f. detail of petiole with gland; g. longitudinal cut of the flower; h. fruit; i. seed. j-n. Passiflora tetraden - j. leaf; k. detail of petiole with gland; 1. longitudinal cut of the flower; $\mathrm{m}$. fruit; n. seed. o-s. Passiflora speciosa - o. leaf; p. detail of the petiole with gland; q. longitudinal cut of the flower; $\mathrm{r}$. fruit; $\mathrm{s}$. seed. Drawn by Luiz Menini Neto. (a-d. A.M. Moraes et al. 340; e,f,h. A.M. Moraes et al. 302; g. N.M. Farinazzo et al. 2; i. A.M. Moraes et al. 302; j,k,1. A.M. Moraes \& A.P.G. Faria 288; m. A.M. Moraes et al. 322; n. Salimena 52859; p. A.M. Moraes et al. 299; o,q-s. A.M. Moraes 287) 
pedunculadas; pedúnculos 2,5-1 cm compr. Brácteas 2,5-4,9 × 2,2-4,3 cm compr., alternas, ovada a orbicular, ápice agudo a acuminado, base cordada, margem inteiras, cedo caducas, conjunto de três brácteas, com uma bráctea menor abaixo das duas maiores. Flores brancas a roxas; pedicelo 4-6 mm compr.; sépalas 2-3 × 1-1,5 cm, verdeclaro, ovadas, ápice arredondado, oblonga-ovadas; pétalas brancas a levemente roxas, oblonga-ovadas, ápice agudo a arredondado; corona pentasseriada, base alva, ápice bandeado de azul e branco, filamentos bandeados de branco, azul, roxo a vináceo, os externos 2,4-4,5 cm compr., duas series de filamentos maiores, bandeadas de roxo, vináceo e branco, livres, filiformes, ápice agudo, os internos 0,5-2 mm compr., três series reduzidas, tuberculiformes, clavados e/ou dentiformes, ápice arredondado, espatulado e truncados; opérculo membranoso 3-7 mm compr., encurvado, ápice crenulado; límen cupuliforme; coluna do androginóforo 1,1-1,5 cm compr.; filetes 5-8 mm compr., anteras 6-7 × 2-4 mm; ovário 4-7 × ca. $3 \mathrm{~mm}$, ovoide, glabro; estiletes 5-8 mm compr. Frutos bagas 2,2-2,6 × 1,5-2 cm, verdes claro ou amarelados, ovoides, glabros. Sementes 3-4×2-3 $\mathrm{mm}$, obovadas, ápice com um corno, base aguda, testa reticulo-foveada.

Material examinado: Araponga, PESB, 8.II.1989, bot., A.O. Scariot et al. 371 (CESJ, IAC); Fazenda Brigadeiro, 14.I.2015, fl. e fr., A.M. Moraes et al. 322 (CESJ). Fervedouro, PESB, Trilha Pedra do Pato, 18.IX.2014, bot. e fl., A.M. Moraes et al. 288 (CESJ). Carangola, PESB, 1.V.1991, fl., L.S. Leoni 19549 (UPCB). Ervália, PESB, Serra do Tabuleiro, 26.II.2015, bot., A.M. Moraes \& L.P. Gurgel 349 (CESJ).

Passiflora tetraden é uma espécie endêmica do Brasil e do domínio Atlântico. Distribui-se em toda a Região Sudeste e no estado da Bahia. Ocorre em Floresta Ombrófila e Floresta Estacional Semidecidual. Comum em florestas primárias de encosta, também podendo ocorrer em capoeiras e capoeirões, em vegetação de restinga (Cervi 1997) e em beira de estradas. Foi coletada no PESB em áreas abertas, e em diversos ambientes como Floresta Ombrófila, bordas de trilhas e beira de estradas (Fig. 20).

Foi coletada em setembro com flor e em janeiro com flor e fruto. Indivíduos jovens de $P$. tetraden foram geralmente encontrados com os lobos laterais das folhas mais proeminentes do que quando adultos. No entanto, suas folhas não possuem grande variação fenotípica, comparadas às das demais espécies citadas.
Pode ser identificada pelo hábito escandente e herbáceo, lâminas foliares inteiras, ovadas, apice obtuso, ligeiramente 3-lobado com lobos laterais reduzidos e lobo médio mais proeminente, dois pares de glândulas pedunculadas no pecíolo, estípulas semi-ovadas, flores brancas com filamentos da corona pentasseriado, com os filamentos externos bandeados de azul, branco e roxo a vináceo.

\section{Conclusão}

O Parque Estadual da Serra do Brigadeiro apresentou riqueza de espécies da família Passifloraceae similar às outras áreas já amostradas no estado de Minas Gerais e em outros estados. Em média foram encontradas de 6 a 12 espécies de Passifloraceae por área já estudada no estado. Algumas espécies estão enquadradas em alguma categoria de ameaça de extinção regional, enfatizando a importância de estudos taxonômicos, ecológicos e fitogeográficos como subsídios a sua conservação.

A distribuição por altitude demonstrou existência das espécies acima de $1.000 \mathrm{~m}$, como observado em Passiflora alata e $P$. rhamnifolia, adaptadas à altitude acima de $1.700 \mathrm{~m}$. Passiflora mediterranea e $P$. speciosa encontraram no PESB condições propícias para seu desenvolvimento e distribuição frequente. Foi observado que no estado de Minas Gerais, a distribuição de $P$. filamentosa é restrita ao PESB.

Este estudo demonstrou que existem particularidades ecológicas que devem ser mais exploradas em Passifloraceae, para compreender melhor sua distribuição geográfica e em diferentes tipos de vegetação, bem como as relações ecológicas entre suas espécies e aspectos relacionados à estrutura de suas populações, contribuindo, assim, para sua conservação.

\section{Agradecimentos}

À Fundação CAPES, a concessão da bolsa de Mestrado à primeira autora; aos curadores dos herbários, que concederam acesso às suas coleções botânicas, e materiais de empréstimos e consulta em visitas realizadas; ao CESJ, ao PGECOL, ao ITR - UFRRJ, à diretoria, e aos funcionários do Parque Estadual da Serra do Brigadeiro, o apoio.

\section{Referências}

Beentje HJ (2012) The Kew plant glossary. Vol. 1. Royal Botanic Gardens, Kew, Chicago. 164p. 
Benites VM (1997) Caracterização química e espectroscópica da matéria orgânica e suas relações com a gênese de solos da Serra do Brigadeiro, Zona da Mata Mineira. Dissertação de Mestrado. Universidade Federal de Viçosa, Viçosa. 123p.

Benites VM, Schaefer CEGR, Mendonça ES \& Martin Neto L (2001) Gênese morfologia e classificação do solo. Caracterização da matéria orgânica e micromorfologia de solos sob campos de altitude no Parque Estadual da Serra do Brigadeiro (MG). Revista Brasileira de Ciência do Solo 25: 661-674.

Bernacci LC, Melleti LMM, Soares-Scott MD, Passos IRS \& Junqueira NTV (2005) Espécies de maracujá: caracterização e conservação da biodiversidade. In: Faleiro FG, Junqueira NTV \& Braga MF (eds.) Maracujá: germoplasma e melhoramento genético. Embrapa, Planaltina. Pp. 559-586.

Bernacci LC, Mezzonato AN \& Salimena FRG (2014) A new threatened species of Passiflora section Decaloba (Passifloraceae) from Minas Gerais state, Brazil. Systematic Botany 39: 517-522.

BFG - The Brazil Flora Group (2015) Growing knowledge: an overview of seed plant diversity in Brazil. Rodriguésia 66: 1085-1113.

Cervi AC (1994) Studies in Brazilian Passifloraceae III. A new species of Passiflora. The New York Botanical Garden 46: 144-146.

Cervi AC (1996) Passifloracece da região de Carangola - Minas Gerais, Brasil. Pabstia 7: 1-32.

Cervi AC (1997) Passifloraceae do Brasil. Estudo do gênero Passiflora L., subgênero Passiflora. Fontqueria 44: 92.

Cervi AC (2006) A new species of Passiflora (Passifloraceae) from Minas Gerais, Brazil. Brittonia 58: 385-387.

Cervi AC \& Dunaiski Jr. A (2004) Passifloraceae do Brasil: estudo do gênero Passiflora L. subgênero Distephana (Juss.) Killip. Brazilian Passifloraceae: study of the subgenus Distephana (Juss.) Killip of the genus Passiflora L. Revista de Estudos de Biologia 26: 45-67.

Cervi AC, Bernacci LC \& Nascimento DS (2009) Passifloraceae. In: Stehmann JR, Forzza RC, Salino A, Sobral M, Costa DR \& Kamino LHY (eds.) Plantas da Floresta Atlântica. Vol. 1. Instituto de Pesquisas Jardim Botânico do Rio de Janeiro, Rio de Janeiro. Pp. 498-499.

CRIA - Centro de Referencia de Informação Ambiental (2011) Specieslink - simple search. Disponível em $<$ http://www.splink.org.br/index $>$. Acesso em 10 dezembro 2015.

Consema - Conselho Estadual do Meio Ambiente, Rio Grande do Sul (2003) Decreto estadual Consema 42.099 de 2002: espécies da flora nativa ameaçadas de extinção no estado do Rio Grande do Sul. Diário Oficial do Estado do Rio Grande do Sul, Porto Alegre. 15p.

Cutri L, Nave N, Ami MB, Chayut N, Samach A \& Dornelas MC (2013) Evolutionary, genetic, environmental and hormonal-induced plasticity in the fate of organs arising from axillary meristems in Passiflora spp. Mechanisms of Development 130: 61-69.

Deginani NB (2001) Las especies argentinas del género Passiflora L. (Passifloraceae). Darwiniana 39: 43-129.

Dewalt SJ, Schnitzer SA \& Denslow JS (2000) Density and diversity of lianas along a chronosequence in a central Panamanian lowland forest. Journal of Tropical Ecology 16: 1-19.

Engevix (1995) Caracterização do meio físico da área autorizada para criação do Parque Estadual da Serra do Brigadeiro. Relatório Técnico Final dos Estudos 8296- Re-H4-003/94. Instituto Estadual da Floresta, Bird/Pró-Floresta/Seplan, Belo Horizonte. 34p.

Farinazzo NM \& Salimena FRG (2007) Passifloraceae na Reserva Biológica da Represa do Grama, Descoberto, Minas Gerais, Brasil. Rodriguésia 58: 823-833.

Fontes AL, Fonseca RSF, Bernacci LC \& Vieira MF (2013) Passifloraceae da Mata do Paraiso. In: Reserva Florestal Mata do Paraíso, Viçosa, Minas Gerais, Brasil. Rapid Color Guide. Nº 374. Disponível em < http://fieldguides.fieldmuseum. org/sites/default/files/rapid-color-guides-pdfs/374. pdf $>$. Acesso em 10 setembro 2014.

Gentry A (2009) The distribution and evolution of climbing plants. In: Putz FE \& Mooney HA (eds.) The Biology of Vines. Cambridge University Press, New York. Pp. 3-52.

Hammer O, Harper DAT \& Ryan PD (2001) Past: paleontological statistics software package for education and data analysis. Palaeontologia Electronica. Vol. 4, nº.9, 9p. Disponível em $<$ http:// palaeo-electronica.org/2001_1/past/issue1_01. $\mathrm{htm}>$. Acesso em 24 setembro 2015.

Harris JG \& Harris MW (2001) Plant identification terminology. $2^{\mathrm{a}}$ ed. Vol. 1. Spring Lake Publishing, Spring Lake. Pp.136-202.

Hilgenhof R (2012) Passiflora subgenus Astrophea curiosities amongst the Passionflowers. Dissertation. Kew Botanic Gardens, Kew. 111p.

ICMBio - Instituto Chico Mendes (2013) Aplicação de critérios e categorias da UICN na avaliação da fauna brasileira. ICMBio, Brasília. 45p. Disponível em <http://www.icmbio.gov.br/cepsul/images/ stories/especies_ameacadas/publicacoes/2013 apostila_aplicacao_criterios_categorias_UICN versao 2.0.pdf $>$. Acesso em 10 outubro 2015.

Imig D (2013) Estudo taxonômico da família Passifloraceae Juss. no Distrito Federal, Brasil. Dissertação de Mestrado. Universidade Federal do Paraná, Curitiba. 100p.

IUCN - International Union for Conservation of Nature (2011) IUCN Red List Categories - Version 3.1. IUCN Species Survival Commission. IUCN, Gland, Cambridge. $2^{\text {nd }}$ ed., 2012. Disponível em $<$ http:// 
www.iucnredlist.org/documents/redlist cats crit sp.pdf $>$. Acesso em 10 outubro 2015.

Killip EP (1938) The American species of Passifloraceae. Field Museum Natural History, Botanical Series 19: 1-603.

Köppen W (1948) Climatologia. Fondo Cultura Económica, México, Buenos Aires. 478p.

Leoni LS (1992) Lista de plantas vasculares do Parque Estadual da Serra do Brigadeiro, Minas Gerais. Pabstia 3: 1-13.

Leoni LS \& Tinte VA (2004) Flora do Parque Estadual da Serra do Brigadeiro: caracterização da vegetação e lista preliminar das espécies. Vol. 1. Ed. São José, Carangola. 91p.

Longo JM (2002) Ecologia da Polinização de Passiflora speciosa Gardner. (Passifloraceae) no Pantanal Sul-Matogrossense. Dissertação de Mestrado. Universidade Federal do Mato Grosso do Sul, Campo Grande. 38p.

Martinelli G \& Moraes MA (2013) Livro vermelho da flora do Brasil. Centro Nacional de Conservação da Flora - CNC Flora, Rio de Janeiro. 1100p.

Mezzonato-Pires AC, Salimena FRG \& Bernacci LC (2013) Passifloraceae na Serra Negra, Minas Gerais, Brasil. Rodriguésia 64: 123-136.

Milward-de-Azevedo MA \& Baumgratz JFA (2004) Passiflora L. subgênero Decaloba (Dc.) Rchb. (Passifloraceae) na Região Sudeste do Brasil. Rodriguésia 55: 17-54.

Milward-de-Azevedo MA (2007) Passifloraceae do Parque Estadual de Ibitipoca, Minas Gerais. Boletim de Botânica Universidade de São Paulo 25: 71-79.

Milward-de-Azevedo MA, Baumgratz JFA \& GonçalvesEsteves VA(2012) Taxonomic revision of Passiflora subgenus Decaloba (Passifloraceae) in Brazil. Phytotaxa 68: 1-68.

MMA - Ministério do Meio Ambiente (2007) Áreas prioritárias para a conservação, uso sustentável e repartição de benefícios da biodiversidade brasileira. $2^{\mathrm{a}}$ ed. Ministério do Meio Ambiente, Secretaria de Biodiversidade e Florestas, Brasília. 300p.

MAA - Ministério do Meio Ambiente (2014) Portaria MMA n ${ }^{\circ} 443$, de 17 de dezembro de 2014. Lista nacional oficial de espécies da flora ameaçada de extinção. Brasília, DF, 17 dez. 2014. Disponível em <http://cncflora.jbrj.gov.br/portal/static/pdf/ portaria_mma 443 2014.pdf $>$. Acesso em 23 setembro 2015 .
Minas Gerais - Secretaria de Estado de Meio Ambiente e Desenvolvimento Sustentável (Semad) (2007) Plano de Manejo do Parque Estadual da Serra do Brigadeiro. Instituto Estadual de Florestas (IEF), Belo Horizonte. 90p.

Moat J (2007) Conservation assessment tools extension for ArcView 3.x, version 1.2. GIS Unit, Royal Botanic Gardens, Kew. Disponível em $<$ http://www. rbgkew.org.uk/gis/cats>. Acesso em 20 setembro 2015.

Oliveira JC \& Ruggiero C (2005) Espécies de maracujá com potencial agronômico. In: Faleiro $\mathrm{FG}$, Junqueira NTV \& Braga MF (eds.) 19 ${ }^{\text {a }}$ ed. Maracujá: germoplasma e melhoramento genético. Embrapa Cerrados, Brasília. Pp. 141-158.

Pérez-Cortéz S, Tillett S \& Escala M (2002) Estudio morfológico de la semilla de 51 especies del gênero Passiflora L. Acta Botánica Venezuelica 25: 1-44.

Porter-Utley K (2014) A review of Passiflora L. subgenus Decaloba (Dc.) Rchb. Super section Cieca (Medik.) JM. Macdougal \& Feuillet (Passifloraceae). Phytokeys 43: 1-224.

Rizzini CT (1977) Sistematização terminológica da folha. Rodriguésia 42: 103-125.

Sacco JC (1980) Passifloráceas. In: Reitz R (ed.) Flora ilustrada catarinense. Fasc. Pass. Herbário Barbosa Rodrigues, Itajaí. 130p.

Schnitzer SA \& Bongers F (2002) The ecology of liana and their role in forest. Trends in Ecology \& Evolution 17: 223-229.

Stearn WT (2004) Descriptive terminology. In: Stearn WT (ed.) Botanical Latin. 4a ed. Vol. 1. Timber Press, Portland. Pp. 204-343.

Thiers B [continuamente atualizado] Index Herbariorum: a global directory of public herbaria and associated staff. New York Botanical Garden's Virtual Herbarium. Disponível em $<$ http://sweetgum.nybg. org/science/ih/>. Acesso em 20 dezembro 2016.

Vaz AMSF, Lima MPM \& Marquete R (1992) Técnicas e manejo de coleções botânicas. In: Veloso HP, Oliveira-Filho LD, Vaz AMSF, Lima MPM, Marquete R \& Brazão JEM. (orgs.) Manual técnico da vegetação brasileira: manuais técnicos em geociências. Vol. 1. IBGE, Rio de Janeiro. Pp. 55-75.

Vitta FA (2006) Flora de Grão Mogol, Minas Gerais: Passifloraceae. Boletim de Botânica da Universidade de São Paulo 24: 9-12. 


\section{Lista de exsicatas}

Salles AJH 3431(11). Salles AJH et al. 3479(11). Duarte AP RB 3711(5), 94494(5), 14242(5). Moraes AM CESJ 285(11), 286(2), 305(1). Moraes AM et al. CESJ 321 (2), 322 (10), 325 (5) 326 (6), 327(6), 328(6), 329 (6), 330(7), 332(6), 333(11), 334 (11), $335(3)$, 337(3), 338(6), 339(6), 340(8), 341(11), 342(1), 344(6), 345 (11), 346(8), 347(8), 363 (9), 364(1). Moraes AM \& Gurgel LP CESJ 348(3), 349(10), 350(2), 351(2), 352(6). Moraes AM \& Faria APG CESJ 287(11), 288(10), 289(1). Moraes AM \& Milward-deAzevedo MA CESJ 290(11), 291(11), 292(11), 293(11), 295(11), 296(11), 297(11), 298(2), 365(3). Moraes AM \& Moraes AM CESJ 302(9), 307(6), 308(6), 309(4), 310(6), 311(6), 312(6), 313(5), 314(11), 315(6), 316(6), 318(6), 319(6), 354(11), 358(8), 359(6). Moraes AM \& Tiburtino RF CESJ 299(11), 301(2), 302(9). Scariot AO et al. IAC 371(10). Cosenza B VIC 26059(6). Pifano DS et al. CESJ 518(7). Lucas EJ et al. ESA, IAC, CESJ 691(11), 687(11). Salimena FRG \& Nobre PH CESJ 2841(4). Siqueira GS RB 818(9). Valente GE et al. VIC 1123(6), 1993(11), 1953(11). Nakajima JN et al. RB 2413 (7). Basilio LA et al. VIC 15581(11). Leoni LS UPCB 2890(2), 3109(4), 19549(10). Leoni LS \& Medeiros C UPCB 19547(6). Kollmann L et al. RG 10598(9). Vieira MF VIC 796(3), 799(2). Vieira MF et al. UPCB, VIC 355(8), 457(11). Sobral M et al. RB 14053(7). Farinazzo NM et al. CESJ 2(9). Moura VS et al. HUEMG 74(6). Vidal WN et al. VIC 704(6).

Editor de área: Dr. Luiz Menini Neto Artigo recebido em 27/12/2016. Aceito para publicação em 30/06/2017. This is an open-access article distributed under the terms of the Creative Commons Attribution License. 